\title{
Food of the Squid Nototodarus gouldi in Bass Strait
}

\author{
D. O'Sullivan ${ }^{\mathrm{A}}$ and J. M. Cullen ${ }^{\mathrm{B}}$ \\ A Antarctic Division, Channel Highway, Kingston, Tas. 7150. \\ ${ }^{\mathrm{B}}$ Department of Zoology, Monash University, Clayton, Vic. 3168.
}

\begin{abstract}
A study was carried out on the food of the squid $N$. gouldi, based on 1277 individuals collected by Japanese vessels jigging in Bass Strait from November 1979 to April 1980. Most of the food consisted of crustaceans, fish and cephalopods, with crustaceans being more common in smaller animals and cephalopods in larger ones. The crustaceans, which included several benthic species, were more common in the diet at night than by day. Cannibalism by $N$. gouldi did not appear to increase appreciably after the animals. were brought aboard and laid together in the collecting troughs. By frequency of occurrence, the contributions to the diet, averaged over all sizes sampled, were fish $37 \%$, crustaceans $36 \%$, and squid $26 \%$; but in terms of biomass fish contributed more. From the size of the beaks of squid taken, it could be shown that the mantle length of these prey was usually not more than half that of the predator. $N$. gould $i$ feeds primarily at night, probably moving up from the bottom into the water column. Larger specimens, both male and female, were less likely to contain food in the stomach than smaller ones, and possible explanations are considered. There are some indications about the timing of spawning in 1979-1980, from records of the size and sexual maturation of the animals sampled.
\end{abstract}

\section{Introduction}

In recent years, there has been increased interest in the biology of pelagic cephalopods of the family Ommastrephidae, largely because of their new importance as human food (Arnold 1979). Much of this work has focused on Todarodes pacificus (Steenstrup) of the north-west Pacific and Illex illecebrosus (Le Sueur) of the north-west Atlantic. About 10 years ago, research began on Nototodarus sloani (Gray) of New Zealand waters as it started to be fished by Japanese squid vessels (Saito et al. 1974; Kawakami 1976; Roberts 1978). Studies of the Australian arrow squid, Nototodarus gouldi (McCoy), have lagged considerably behind but the species is now also beginning to receive attention with the coming of the Japanese squid fishing fleets (Anon. 1978, 1980; Dunning 1983; Harrison 1983; Smith 1983; P. E. Roberts, unpublished data).

$N$. gouldi has been fished for many years, although on a very small scale, and the squid was used as bait for commercial and amateur line fishermen and later for the Japanese long-line tuna fishery (Slack 1973).

The currently known distribution of $N$. gouldi is from the Great Australian Bight to southern Queensland (Wormuth 1976). Allan (1945) found rhynocoteuthion larvae characteristic of ommastrephids in shallow water and on the continental shelf off the New South Wales coast and tentatively identified these as $N$. gouldi. During the summer, $N$. gouldi is reported to undergo an inshore migration (Wolfe 1973) with large concentrations of squid occurring in the Derwent estuary, Spencer Gulf and Bass Strait (Slack 1973). Estimates that the potential of the squid resources are substantial led to the establishment of a feasibility study of the squid fishery (Anon. 1978). 
Scientific interest in the squid has grown with the expansion of commerical fishing, especially as the squid may be an important part of the food webs of the area, being found in the stomachs of many commerical fish (Cotton 1942; Allan 1945; Winstanley 1978), as well as mammals and sea birds (Warneke 1976; Clarke 1977; Nelson 1980; Montague, personal communication). This information has been usefully summarized by Roberts (unpublished data).

During four summers, 1977-1981, the Japan Marine Fisheries Resource Centre chartered research vessels to collect information on the distribution, migration and general ecology of $N$. gouldi off the south-eastern coast of Australia. Some of these data have been analysed by Harrison (1983) to establish the viability of a fishery. Although the Japanese studies of $N$. gouldi have included some work on the biology of the squid (Anon. 1978, 1980), there is little detailed analysis of it, either as predator or prey. The purpose of this study was to examine aspects of the diet and feeding of $N$. gouldi. The effect of time of day, and the influence of squid gender, maturation and body size on feeding were also considered.

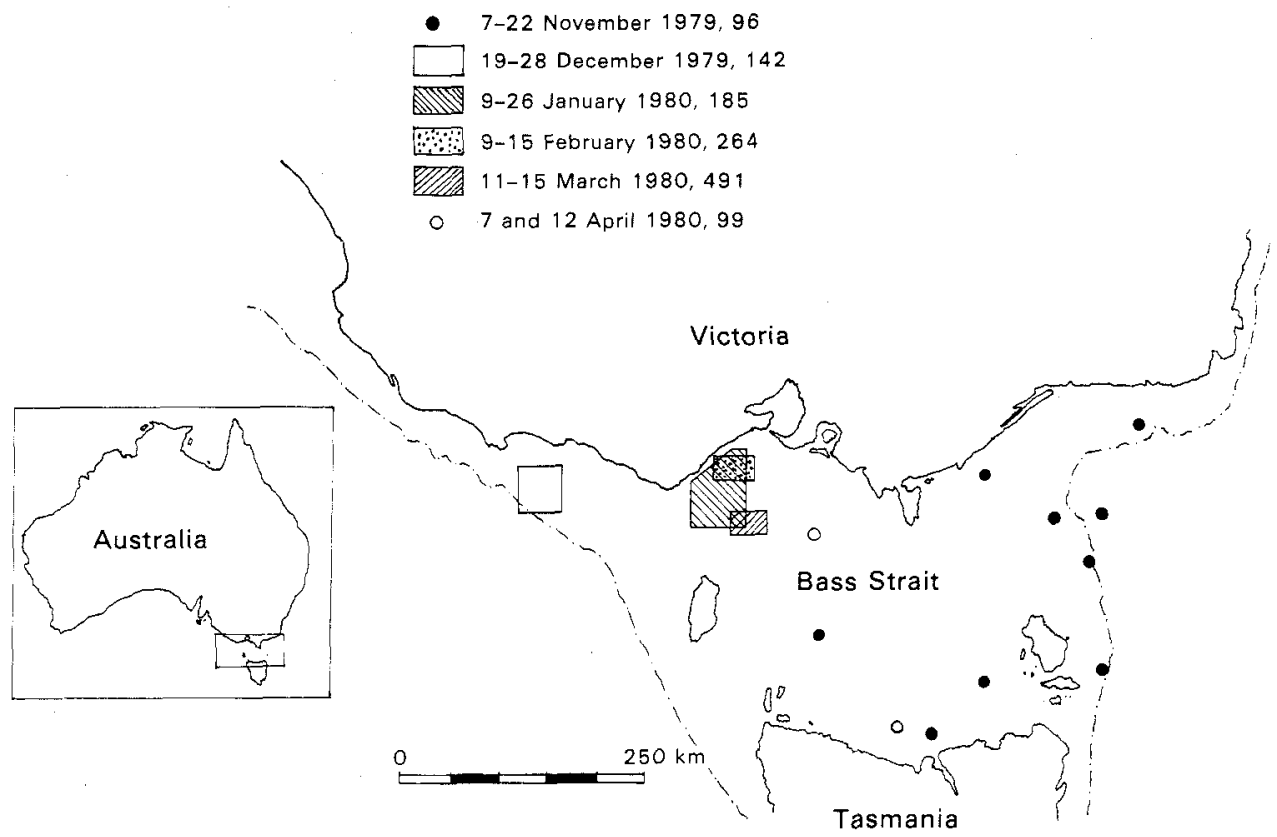

Fig. 1. Locations of sampling sites in Bass Strait. Dates of sampling and numbers of squid collected are indicated. - . - 200-m Isobath.

\section{Materials and Methods}

Specimens for this project came from the catch of the Japanese squid jigging vessels, which operated in south-eastern Australian waters from November 1979 to April 1980 (see Fig. 1). Many of these vessels were accompanied by an observer selected by the Fisheries and Wildlife Division, Victorian Ministry for Conservation; D.O.S. went with the research vessel Hoya Maru 67 in February and March 1980.

Since there seem to be few published accounts of this kind of fishing, the following description is given. In the late afternoon, the squid boat searches for squid concentrations, using an echo-sounder. Once squid are found, a parachute anchor is set and this, in conjunction with a fixed double-mizzen sail, reduces roll and holds the vessel head-to-wind. About half-an-hour before sunset, 30-50 4-5-kW fishing lamps are turned on and remain on during fishing until about half-an-hour after dawn. Along 

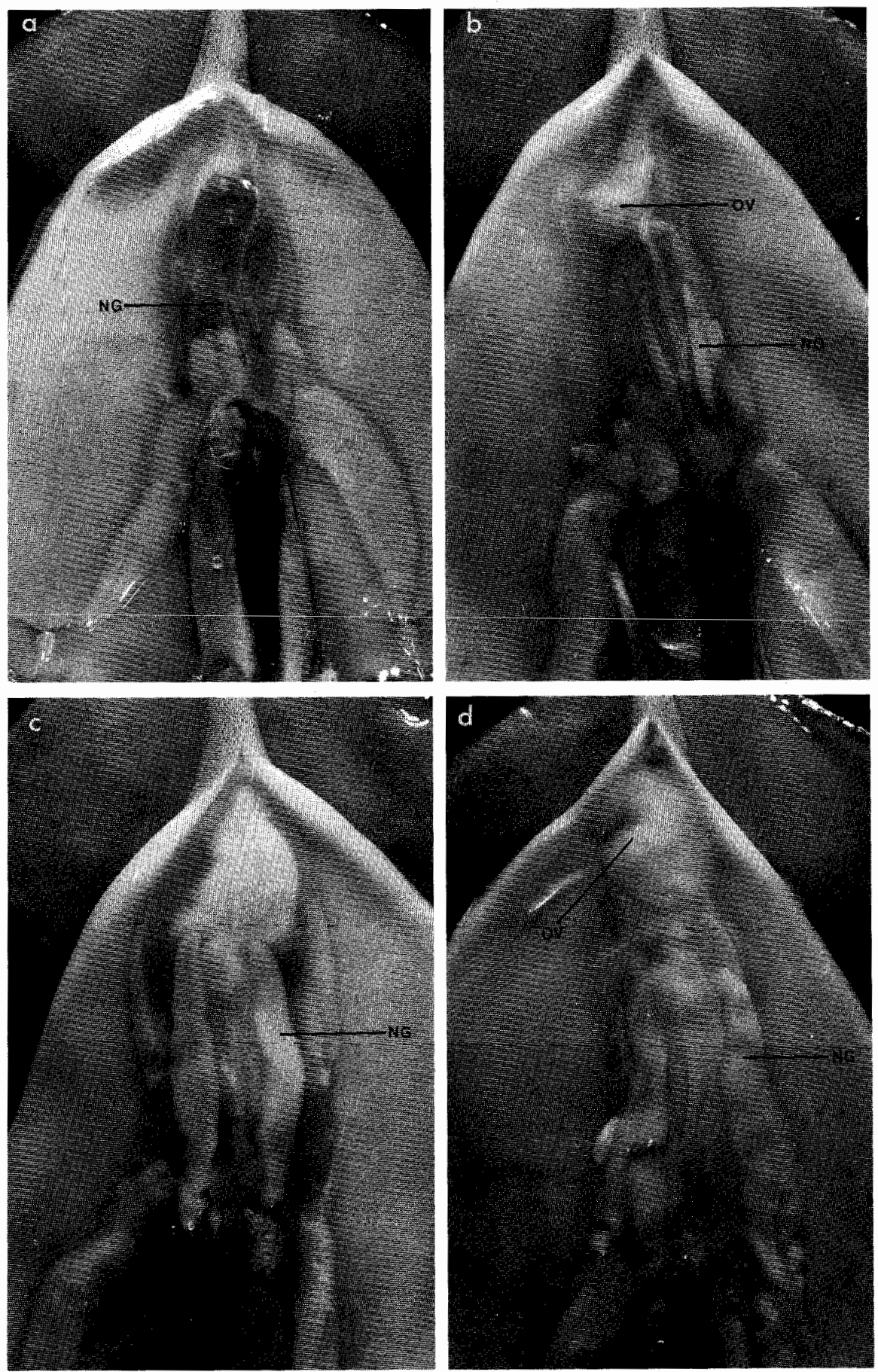

Fig. 2. Maturation stages of female N. gouldi: $(a)$ immature; $(b)$ maturing; $(c)$ mature; $(d)$ ready to spawn. $N G$, nidamental gland; $O V$, ovary. 
the gunwales of the boat, automatic jigging machines are spaced at intervals of about $2 \mathrm{~m}$. Each machine consists of two elliptical reels driven by an electric motor, a plastic-coated wire mesh screen and a pair of guide rollers. The screen and guide rollers hang out over the side at about $30^{\circ}$ to the horizontal. The lines that are wound on the reels usually carry about 20 jigs (spindle-shaped coloured lures with a double ring of unbarbed hooks) spaced $1 \mathrm{~m}$ apart and each ends in a $1-2-\mathrm{kg}$ lead sinker. Under the weight of the sinkers, the lines run out freely to a predetermined depth, usually about $10 \mathrm{~m}$ above the sea floor. Then the gears engage and the lines are wound up in a jerking motion caused by the shape of the reels. When the squid attacks a jig, it is caught by the crown of hooks, pulled to the surface and over the guide rollers, and is jerked off the line to fall on to the wire mesh screen. From here, the squid either roll or are placed manually into gutters running along the side of the boat beneath the machines. The squid are then washed into collection bins, sorted into size categories and packed into trays before freezing. Once the line is fully wound in, it runs out again and the whole cycle is repeated.

Squid can also be caught by hand jigging. The hand line with three or four chrome-plated jigs is lowered to the bottom and tugged up and down a metre or so until a squid is felt attacking the jigs. The line is then quickly pulled in by the fisherman and the squid is dropped into the collection gutter.

Samples for this study were collected each month, most squid being caught by the automatic machines. Here a 'sample' means a number of animals, usually 10-25, collected within $1 \mathrm{~h}$ of each other. The collection dates are shown in Fig. 1 and the number of squid collected each month in Figs 1 and 5. Except for some of the samples collected in February and all of those collected in March and April, the squid were collected at various times during the night only. In February and March, the samples were collected throughout 24 -h periods according to a predetermined schedule to focus sampling effort at times around dusk (1700-2159 h) and dawn (0300-0759 h) when it was thought there might be a change in feeding pattern. During March, the catch rate per machine hour was recorded at selected times during $24 \mathrm{~h}$. The procedure for jigging by day was exactly the same as at night except that the nishing lights were not on.

During examination of the early samples, it was noticed that many of the squid had pieces of flesh missing. To find out whether this was due to cannibalism after capture, special care was taken during February and March to remove the squid and freeze them immediately they were brought aboard.

Time (Australian Eastern Standard Time), water depth (m), location, surface water temperature $\left({ }^{\circ} \mathrm{C}\right)$, weather and catch rates were recorded, and labelled squid samples were packed into trays before being placed in the snap freezer. Freezing at $-60^{\circ} \mathrm{C}$ inhibited further digestion.

For subsequent analysis in the laboratory, the individual blocks of frozen squid were thawed as quickly as possible. Each squid was numbered and the following determined:

(1) Dorsal mantle length (ML). Mantle length was measured to the nearest millimetre from the anterodorsal protruberance of the mantle to the apex of the tail fin. This length is less variable than a measurement of the total length, which is dependent on the degree of stretch of the arms and tentacles.

(2) Total body weight (BW). Excess water was drained from the squid for approximately $30 \mathrm{~s}$ and the total wet weight determined to the nearest gram on a Mettler PL 1200 electronic balance.

(3) Beak. Rostral length of the lower beak was measured to the nearest tenth of a millimetre using Vernier callipers (Clarke 1962).

(4) Sex and maturation. These were recorded by measurement of selected reproductive organs and by scoring on a scale from 1 to 4 using criteria broadly similar to those developed by Mercer (1973) and Amaratunga and Durward (1979).

Females. (a) Maturation index: stage 1 (immature), nidamental glands very thin and transparent to translucent (Fig. 2a); stage 2 (maturing), nidamental glands still thin but milk-white (Fig. $2 b$ ); stage 3 (mature), nidamental glands thick and creamy and ovary large (Fig. 2 c); stage 4 (ready to spawn), ovary full of ripe eggs and nidamental glands large (Fig. 2d). (b) Measurement: the right nidamental gland was measured to the nearest millimetre. Spermatophores can be present around the mouth of the female from stage 2 .

Males. (a) Maturation index: stage 1 (immature), Needham's sac very small and transparent to translucent, little differentiation of penis and seminal vesicle; stage 2 (maturing), Needham's sac whitish, penis and seminal vesicle evident (Fig. 3a); stage 3 (mature), seminal vesicle contains spermatophores but penis does not (Fig. 3b); stage 

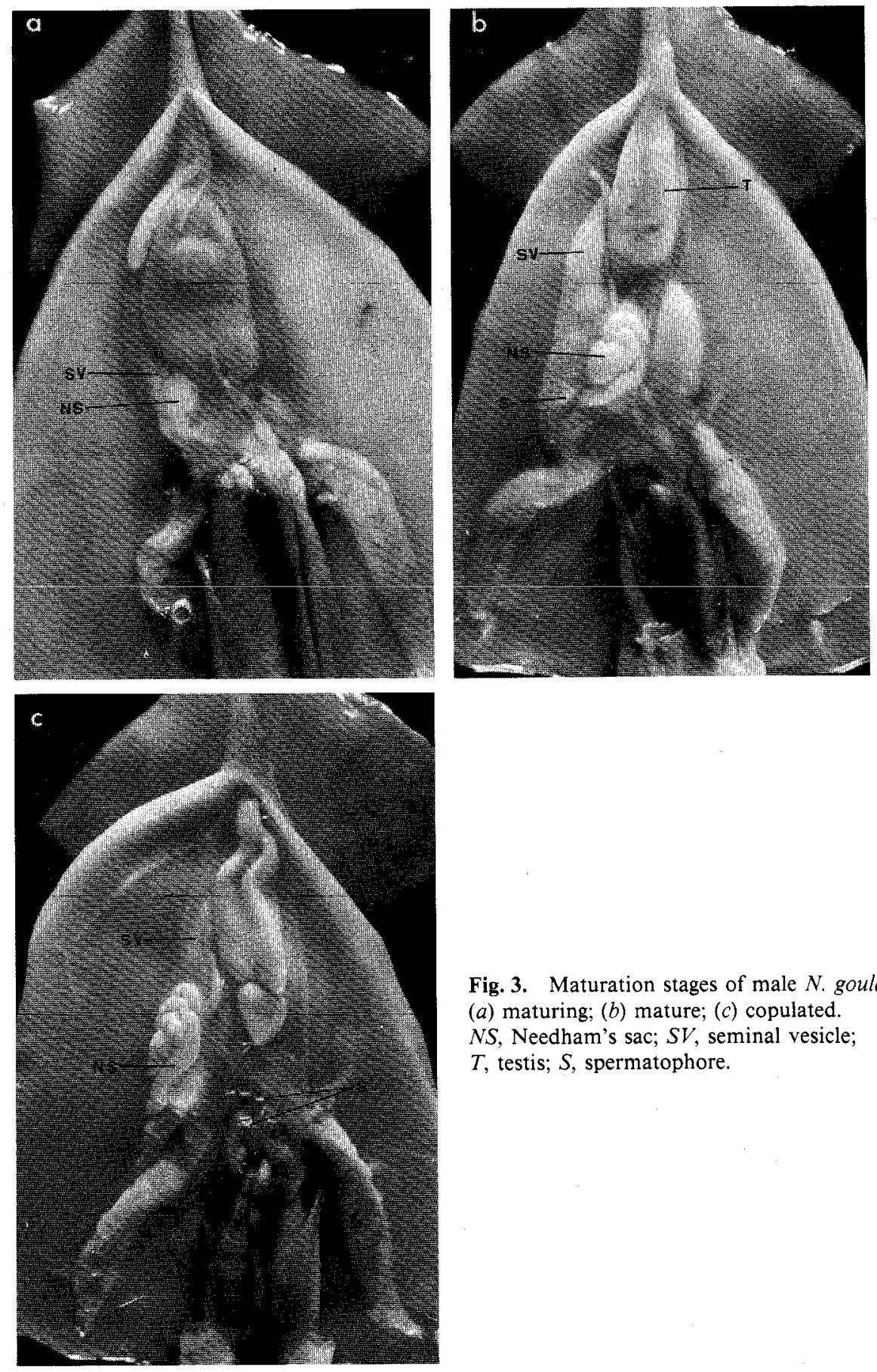

Fig. 3. Maturation stages of male $N$. gouldi: (a) maturing; (b) mature; (c) copulated. $N S$, Needham's sac; $S V$, seminal vesicle; $T$, testis; $S$, spermatophore. 
4 (copulated), very few spermatophores in seminal vesicle and penis but some may be present in mantle cavity (Fig. $3 c$ ). (b) Measurement: in the samples collected in March and April, the total length of the penis, Needham's sac and seminal vesicle was measured to the nearest millimetre.

(5) Fullness of digestive tract (gut). Two methods were used: a subjective scoring of the fullness of each of the four parts of the gut, and the weight of the whole tract, including any food it contained. It was not possible to weigh the contents separately, so the whole digestive tract (buccal mass, beak, oesophagus, stomach, caecum and rectum) was removed and weighed to the nearest $0.1 \mathrm{~g}$ on a Mettler balance. The gut weight expressed as a percentage of total body weight was taken to be the standard measurement of fullness, though it was not very satisfactory (see Results). Initially, the whole gut was then preserved in $10 \%$ formalin but when it was found that this method dissolved fish otoliths the rest of the samples were preserved in $70 \%$ ethanol.

The stomach and caecum were later dissected and a fullness index recorded using criteria comparable with those developed by Amaratunga and Durward (1979): 0 (empty), 1 (food present but stomach or caecum less than one-quarter full), 2 (one-quarter to half full), 3 (greater than half full but not distended), 4 (distended). Even when empty, the caecum never becomes so shrunken relative to its size as the stomach, but as it fills a pouch extending posteriorly becomes more pronounced (Fig. 4). The presence of food particles in the oesophagus and rectum were recorded as 0 (nil), 1 (less than half full) and 2 (half full or greater). Any mucus or digestive fluid that was present was ignored in the determination of these fullness indices.

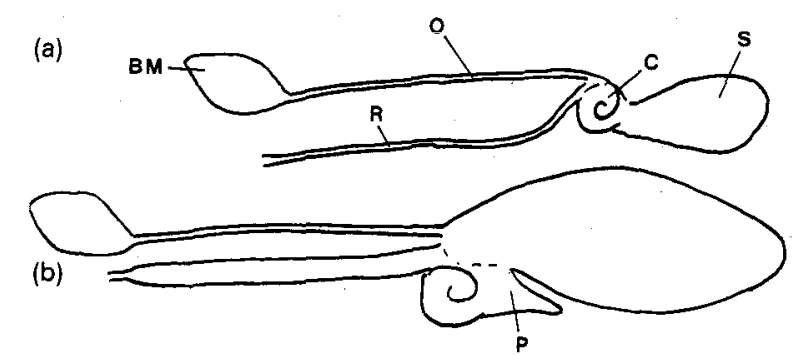

Fig. 4. Stages of gut fullness to indicate fullness indices for the oesophagus, stomach, caecum, and rectum, respectively. (a) $0,0,0,0 ;$ (b) $0,4,4,4$. $B M$, buccal mass; $O$, oesophagus; $C$, caecum; $S$, stomach; $R$, rectum; $P$, caecal pouch.

(6) Analysis of gut contents. Identifiable food was present mainly in the stomach and rectum, and, less commonly, in the caecum. The prey items were sorted and identified using a dissecting microscope. Any distinguishable food pieces (i.e. scales, otoliths, beaks, sucker rings, crustacean bodies, etc.) were separated from the gut and kept for further identification. A single animal might contain more than one species of food.

The food items were identified to the lowest taxonomic level possible (see Acknowledgments). To estimate the amount of the different species in the food of the squid, the frequency of occurrence (Windell 1971) was calculated, i.e. the number of squid in which a particular food item occurred, divided by the total number of squid examined. This measure is affected by the number of animals with empty guts or unidentified food. The percentage occurrence of different food types, summed across the food types, will not usually total $100 \%$ because some stomachs are empty and others contain two or more food types. For some purposes it was convenient to use a measure that summed across food types to $100 \%$. This was called the 'percentage in the diet' and calculated for each taxon:

$$
100 \times f_{a} / \Sigma f
$$

where $f_{1}, f_{2}, f_{3}$ etc. are the frequency of occurrence of taxa 1,2,3 etc. Thus, if fish, Crustacea and squid have a frequency of occurrence of 70,30 and $20 \%$, respectively, in one month, the percent in the diet of fish is calculated as $70 /(70+30+20)$ as a percent, namely $58 \%$. 
Scales and otoliths were used in the identification of the fish species. Reference specimens of each were taken from identified fish and compared with the scales and otoliths found in the digestive tracts of squid. Fish identified in this way were Sardinops neopilchardus (Steindachner), Hemiramphus melanochir Cuvier \& Valenciennes, Leionura atun (Euphrasen), Atherinason dannevigi (McCulloch) and Scomber australasicus Cuvier \& Valenciennes. Unidentified tish species named by otoliths (OA, $\mathrm{OB}$, etc.) could in some cases be the same as the unidentified fish species named by scales (SA, SB, etc.).

The chitinous beaks of squid resist digestion and often permit identification to family level (Clarke 1962). As a guide to the size of the prey taken, squid beaks found in the digestive tracts were measured where possible (rostral length of the lower beak) as they predict mantle length (see below).

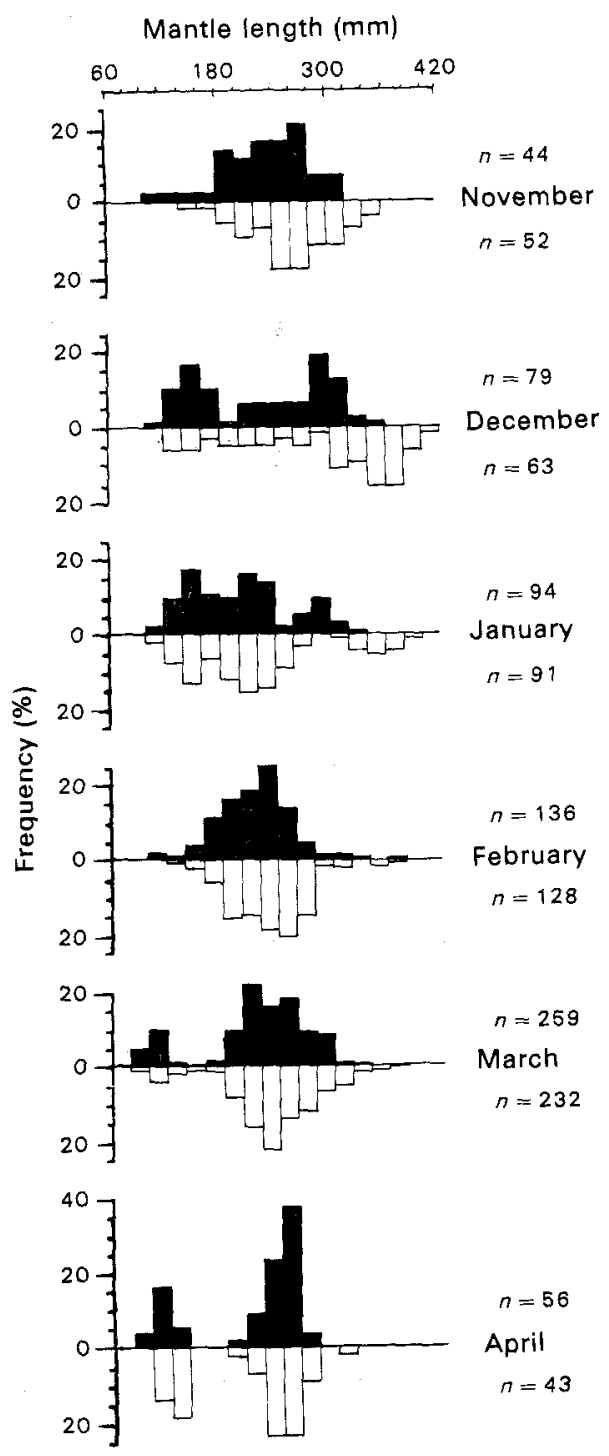

Fig. 5. Frequencies of mantle lengths for males (a) and females $(\square)$ in monthly samples.

\section{Results}

Mantle Length, Body Weight and Beak Size

The dorsal mantle length of the squid ranged from 78 to $401 \mathrm{~mm}$. The percentage frequency of the males and females in $20-\mathrm{mm}$ size classes is shown in Fig. 5 . In all months 
except January and April, the mean mantle length in each 24-h sample of females was significantly longer than that of the males (Table 1). The maximum for the females was $401 \mathrm{~mm}$, for the males $338 \mathrm{~mm}$.

Table 1. Mean sex difference in mantle length of Nototodarus gouldi in each monthly group of samples

Values given are lengths of females minus lengths of males. ${ }^{* *} P<0.01 ;$ n.s., $P>0.05$

\begin{tabular}{lcccc}
\hline Month & $\begin{array}{c}\text { Difference } \\
(\mathrm{mm})\end{array}$ & $t$ & d.f. & $P$ \\
\hline November & $27 \cdot 0$ & $2 \cdot 88$ & 95 & $* *$ \\
December & $64 \cdot 2$ & 5.04 & 141 & $* *$ \\
January & $17 \cdot 4$ & 1.89 & 184 & n.s. \\
February & 13.6 & $2 \cdot 79$ & 263 & $* *$ \\
March & 16.3 & 3.37 & 490 & $* *$ \\
April & -5.4 & -0.45 & 98 & n.s. \\
\hline
\end{tabular}

The relation between body weight ( $W$, in grams) and mantle length ( $L$, in millimetres) closely follows the general relation: $W \propto L^{k}$, with $k$ approximately 3 (Fig. 6). Fitting the data for the different months to the regression of the logarithmic version of the relation,

$$
\log W=\log a+k \log L
$$

allows values of $k$ and $a$ to be calculated. Analysis of variance of the regression coefficients shows that there were no significant differences between the sexes in the coefficients in any month except April (when $k_{q}>k_{\dot{z}}, 0.02<P<0.05$ ). For both sexes, there were significant

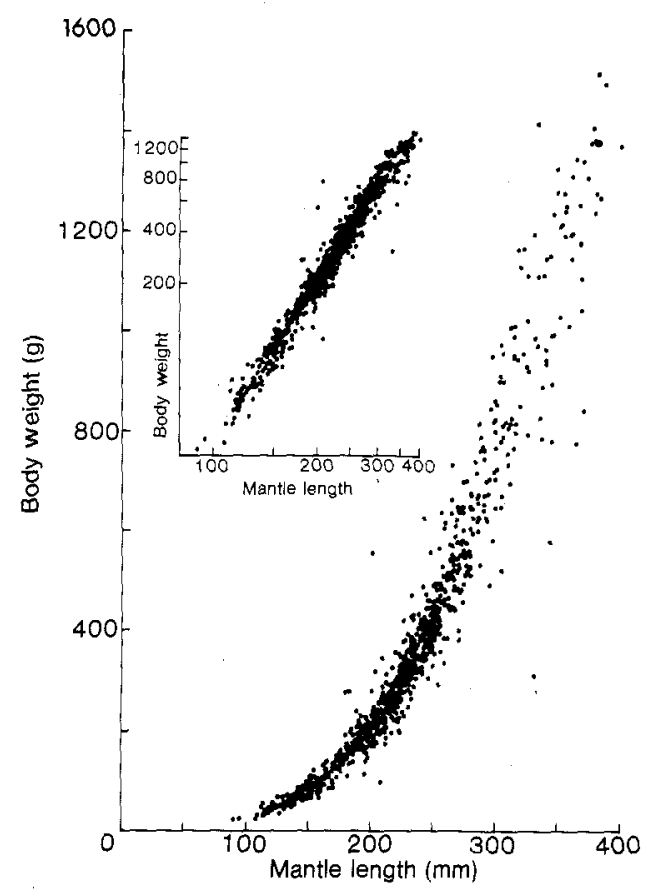

Fig. 6. Relation between mantle length and body weight. Each dot represents one animal. Inset shows same data plotted on $\log -\log$ scale.

monthly differences in slope $(P<0.01$ for ôo, $P<0.025$ for $q q)$ but the variation did not show any consistent pattern for both sexes. For comparison with other studies, the average regression, pooling the months, gives for males: $k$ (s.e. $)=3.099(0.022), a=1.60 \times 10^{-5}$; for females: $k=3.079(0.021), a=1.87 \times 10^{-5}$. 
Fig. 7 shows that the relation between beak and mantle length fits a linear regression and is close to a simple proportional relation.

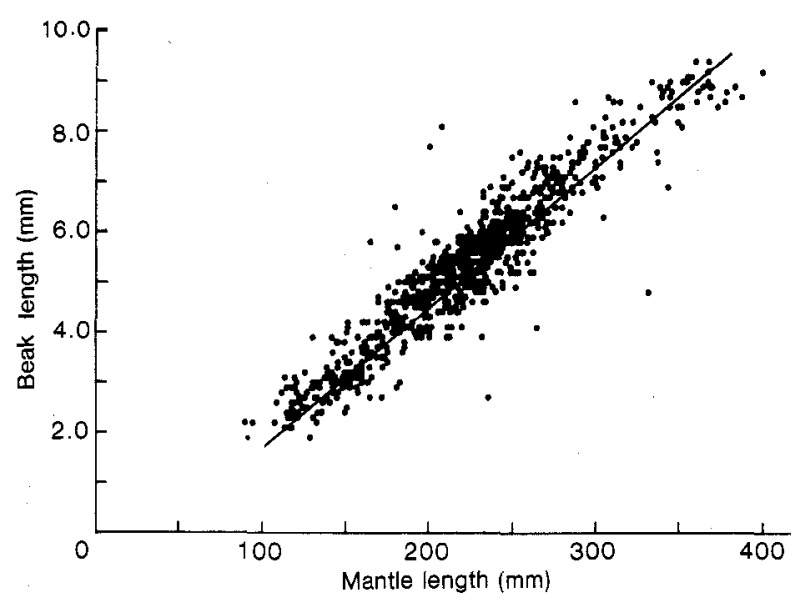

Fig. 7. Relation between mantle length and beak size (rostral length). Regression line is $y=x / 38-0.71$.

\section{Maturation}

As described earlier, the sex-gland length was measured in all 6 months for the females but only in March and April for the males. The maturation index was scored for both

Table 2 Relation between size and sexual maturation of Nototodarus gouldi Precise position of lines dividing mature and immature animals is arbitrary

\begin{tabular}{|c|c|c|c|c|c|c|c|c|c|c|c|c|c|c|c|c|}
\hline \multirow[t]{2}{*}{$\begin{array}{l}\text { Mantle } \\
\text { length } \\
\text { class } \\
\text { (mm) }\end{array}$} & \multicolumn{4}{|c|}{$\begin{array}{c}\text { No. of males } \\
\text { with } \\
\text { maturation } \\
\text { index of: }\end{array}$} & \multirow[b]{2}{*}{ Total } & \multicolumn{4}{|c|}{$\begin{array}{c}\text { No. of females } \\
\text { with } \\
\text { maturation } \\
\text { index of: }\end{array}$} & \multirow{2}{*}{\multicolumn{6}{|c|}{$\begin{array}{c}\text { No. of females with } \\
\text { nidamental gland } \\
\text { length of: }\end{array}$}} & \multirow[b]{2}{*}{ Total } \\
\hline & 1 & 2 & 3 & 4 & & 1 & 2 & 3 & 4 & & & & & & & \\
\hline $60-$ & 1 & & & & 1 & & & & & & & & & & & \\
\hline $80-$ & 13 & & & & 13 & 3 & & & & 3 & & & & & & 3 \\
\hline $100-$ & 40 & & & & 40 & 18 & & & & 18 & & & & & & 18 \\
\hline $120-$ & 24 & & & & 24 & 25 & & & & 25 & & & & & & 25 \\
\hline $140-$ & 34 & 2 & & & 36 & 23 & & & & 23 & & & & & & 23 \\
\hline $160-$ & 33 & 4 & & & 37 & 21 & & & & 21 & & & & & & 21 \\
\hline $180-$ & 13 & 49 & 1 & & 63 & 55 & 3 & & & 57 & 1 & & & & & 58 \\
\hline $200-$ & 8 & 84 & 14 & 2 & 108 & 75 & 7 & & & 81 & 1 & & & & & 82 \\
\hline 220 & 2 & 44 & 52 & 26 & 114 & 73 & 32 & 1 & & 102 & 4 & & & & & 106 \\
\hline $240-$ & & 21 & 55 & 40 & 102 & 32 & 52 & 5 & & 64 & 25 & & & & & 89 \\
\hline $260-$ & & 1 & 13 & 38 & 54 & 8 & 50 & 7 & 2 & 24 & 38 & 3 & 2 & & & 67 \\
\hline $280-$ & & & 14 & & 52 & & 12 & 12 & 1 & & 16 & 8 & 1 & & & 25 \\
\hline $300-$ & & & 7 & 13 & 20 & & 5 & 12 & 13 & & 7 & 9 & 8 & 6 & & 30 \\
\hline $320-$ & & & & 4 & 4 & & 1 & 2 & 15 & & 1 & 2 & 5 & 9 & 1 & 18 \\
\hline $340-$ & & & & & & & & 1 & 21 & & & 1 & 2 & 18 & 1 & 22 \\
\hline $360-$ & & & & & & & & & 16 & & & & & 16 & & 16 \\
\hline $380-$ & & & & & & & & & 5 & & & & & 1 & 4 & 5 \\
\hline $400-$ & & & & & & & & & 1 & & & & & & 1 & 1 \\
\hline
\end{tabular}

sexes in all months. There was a strong correlation between the measurement and the index for both sexes in all months $(P<0.01)$. In the females it ranged from 0.84 to 0.97 over the 6 months; in the males, for which data were available for March and April only, it was 0.93 and 0.90 , respectively. 
Generally, the squid mature as they become larger. Table 2 shows that males matured at a smaller size (ML 220 mm) compared with the females (ML 300 mm). For animals over these sizes, the proportion in the top categories of maturity did not change greatly with month (Table 3). In other words, whatever the time of year, at least in the period November to April, large animals were equally likely to be reproductively mature.

Table 3. Reproductive maturation of large Nototodarus gouldi in different months as indicated by their maturation index and, for females, by their nidamental gland length

Values in parentheses are based on one female only

\begin{tabular}{lccccc}
\hline Month & $\begin{array}{c}\text { No. of males } \\
\text { with mantle } \\
\text { length } \geqslant 220 \mathrm{~mm}\end{array}$ & $\begin{array}{c}\text { \% of males } \\
\text { with maturation } \\
\text { index of } 3 \text { or } 4\end{array}$ & $\begin{array}{c}\text { No. of females } \\
\text { with mantle } \\
\text { length } \geqslant 300 \mathrm{~mm}\end{array}$ & $\begin{array}{c}\text { \% of females } \\
\text { with maturation } \\
\text { index of } 3 \text { or } 4\end{array}$ & $\begin{array}{c}\text { \% of females with } \\
\text { nidamental gland } \\
\text { length } \geqslant 160 \mathrm{~mm}\end{array}$ \\
\hline Nov. & 29 & 86 & 12 & 100 & 33 \\
Dec. & 44 & 88 & 38 & 89 & 79 \\
Jan. & 34 & 91 & 15 & 100 & 87 \\
Feb. & 66 & 74 & 6 & 100 & 33 \\
Mar. & 137 & 79 & 20 & 90 & 40 \\
Apr. & 36 & 69 & $(1)$ & & $(100)$ \\
\hline
\end{tabular}

Copulation (transfer of spermatophores to the female) takes place in some ommastrephid squids some weeks before the females are mature and ready to spawn (Hamabe and Shimizu 1966). If this also applies to $N$. gouldi, then the spawning season(s) is presumably best indicated by the time(s) when large and mature females are most numerous in the population. For our data for 1979-1980 (Fig. 5), this suggests December and January.

\section{Feeding}

Regurgitation or egestion of food or waste matter has been observed in fish during the stress of capture but neither was observed during the collection of squid for this study. The number of squid examined was 1277 , of which $912(71.4 \%)$ had something other

Table 4. Occurrence of each category of food in Nototodarus gouldi

\begin{tabular}{lcccc}
\hline Food category & $\begin{array}{c}\text { No. of } \\
\text { stomachs } \\
\text { containing } \\
\text { food } \\
\text { category }\end{array}$ & $\begin{array}{c}\text { \% of total } \\
\text { No. of squid }\end{array}$ & $\begin{array}{c}\text { \% of total No. of } \\
\text { feeding } \\
\text { squid }\end{array}$ & $\begin{array}{c}\text { Percentage } \\
\text { of } \\
\text { diet }^{\mathrm{C}}\end{array}$ \\
\hline Crustacean & 409 & $32 \cdot 0$ & $44 \cdot 8$ & \\
Fish & 475 & $37 \cdot 2$ & $52 \cdot 1$ & $32 \cdot 6$ \\
Cephalopod & 344 & $26 \cdot 9$ & $37 \cdot 7$ & $27 \cdot 4$ \\
Heteropod & 22 & $1 \cdot 7$ & $2 \cdot 4$ & $1 \cdot 8$ \\
Insect & 4 & $0 \cdot 3$ & $0 \cdot 4$ & $0 \cdot 3$ \\
Not identified & 105 & $8 \cdot 2$ & $11 \cdot 5$ & - \\
Total & 1359 & $106 \cdot 3$ & $148 \cdot 9$ & $100 \cdot 0$ \\
Empty & 365 & & & \\
\hline
\end{tabular}

$+100 \%=1277,{ }^{\mathrm{B}} 100 \%=912 .{ }^{\mathrm{C}} 100 \%=1359-105=1254$.

than mucus in the gut and were called 'feeding animals'. In 105 of these, none of the food was identifiable (Table 4).

Forty-seven different prey categories were recorded from the squid digestive tract, of which 16 were identified to generic or specific level (Table 5). The major food categories were cephalopods, crustaceans and fish; a small number of gastropods (heteropods) and 
insects were also recorded (Table 4). Overall, crustaceans and fish were the most frequent prey items found, with cephalopods ranking third. The totals for the percentage occurrence of food categories in Table 4 exceed 100\% because more than one category of food was often (c. $40 \%$ of individuals) present in a single squid.

It was not possible to identify to species level many of the organisms taken from the digestive tracts but the common species (identified more than 10 times) included two fish (Sardinops pilchardus and Leionura atun) and two crustaceans (Leptochela sydniensis Dakin \& Colefax and Cirolana sp.) with unidentified isopods and amphipods also frequent. Two different kinds of cephalopod beak were found, one characteristic of the family Ommastrephidae, the other of the order Octopoda. Identification cannot be certain as it was not known if other families with characters very similar to those of the ommastrephids and octopods (C. C. Lu, personal communication) occurred in the study area. The ommastrephid species in the prey were separated on the morphology of their sucker rings.

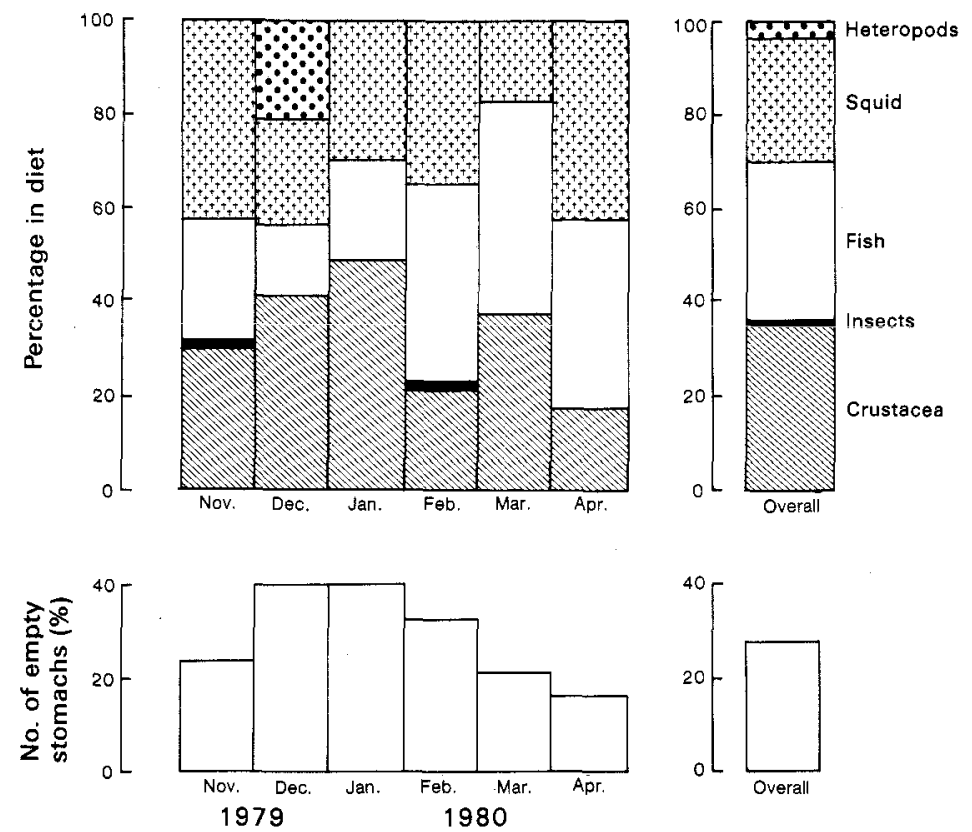

Fig. 8. Histograms showing different food types as percentage of diet in different months, and percentage of empty squid stomachs per month.

Although no doubt the great majority of cephalopod prey belonged to $N$. gouldi, much the commonest neritic squid in Bass Strait, some sucker rings found were like those of Todarodes filippovae Adam, and others could have come from the genera Rossia, Onychoteuthis, Brachioteuthis and Sepioteuthis or from the families Chiroteuthidae or Mastigoteuthidae (C. C. Lu, personal communication).

The frequency of all the prey categories is listed in Table 5. Fig. 8 shows that the proportion of the three main food categories was not the same in the different months $(P<0.01)$.

The size of most prey taken could at best only be roughly estimated and appeared to be always smaller than the mantle length of the feeding animal. It was possible to be more precise when the food was cephalopod; the beaks often remained undamaged when the rest of the body was digested and are a good index of body size (Fig. 7; also Clarke 1962). Fig. 9 shows the relation between the rostral lengths of the prey and of the predators in 
Table 5. Number of squid containing each food type $\mathrm{U}$, unidentified species of taxon indicated

\begin{tabular}{|c|c|c|c|c|c|c|c|}
\hline \multirow[t]{2}{*}{ Prey item } & \multicolumn{6}{|c|}{ No. of squid containing food items in: } & \multirow[t]{2}{*}{ Total } \\
\hline & Nov. & Dec. & Jan. & Feb. & Mar. & Apr. & \\
\hline \multicolumn{8}{|l|}{ Teleosts } \\
\hline \multicolumn{8}{|l|}{ Clupeidae } \\
\hline Sardinops neopilchardus & 5 & & 2 & 39 & 16 & 5 & 67 \\
\hline \multicolumn{8}{|l|}{ Scomberescocidae } \\
\hline Hemiramphus melanochir & 3 & & 1 & & 1 & & 5 \\
\hline \multicolumn{8}{|l|}{ Genpylidae } \\
\hline Leionura atun & & 1 & 5 & 6 & 101 & 19 & 132 \\
\hline \multicolumn{8}{|l|}{ Scombridae } \\
\hline Scomber australasicus & 1 & 1 & & & 2 & & 4 \\
\hline \multicolumn{8}{|l|}{ Atherinidae } \\
\hline Atherinason dannevigi & 1 & & & & & & 1 \\
\hline \multicolumn{8}{|l|}{ Fish 'identified' by otoliths only } \\
\hline $\mathrm{OA}$ & 3 & & & & & & 3 \\
\hline OB & & & 1 & & 8 & 7 & 16 \\
\hline OC & & & & & 2 & & 2 \\
\hline $\mathrm{OD}$ & & & & & 5 & & 5 \\
\hline \multicolumn{8}{|l|}{ Fish 'identified' by scales only } \\
\hline $\mathrm{SA}$ & 3 & & & 1 & & & 4 \\
\hline SB & 1 & & & & & & 1 \\
\hline SC & 1 & & & & & & 1 \\
\hline SD & 1 & & & & & & 1 \\
\hline Unidentified fish & 10 & 13 & 16 & 38 & 172 & 14 & 263 \\
\hline Total No. of squid containing teleosts & 29 & 15 & 25 & 84 & 307 & 45 & 505 \\
\hline \multicolumn{8}{|l|}{ Cephalopods } \\
\hline \multicolumn{8}{|l|}{ Ommastrephidae } \\
\hline U. Ommastrephid & 4 & 1 & 2 & 9 & 38 & 15 & 69 \\
\hline Nototodarus gouldi & 14 & 3 & 13 & 21 & 18 & 5 & 74 \\
\hline Todarodes filippovae & & 1 & & 1 & 3 & 1 & 6 \\
\hline Unidentified squid & 10 & 10 & 6 & 24 & 13 & 1 & 64 \\
\hline Unidentified octopod & 1 & 4 & & & 2 & & 7 \\
\hline Unidentified cephalopod & 10 & 15 & 12 & 17 & 59 & 22 & 135 \\
\hline Total No. of squid containing cephalopods & 39 & 34 & 33 & 72 & 133 & 44 & 355 \\
\hline \multicolumn{8}{|l|}{ Crustaceans } \\
\hline U. Ostrocod & & 1 & & & 1 & & 2 \\
\hline U. Copepod & & & & 1 & & & 1 \\
\hline Calanoides carinatus & 1 & & & & & & 1 \\
\hline U. Mysid & & & & & 1 & & 1 \\
\hline U. Isopod & & 6 & 2 & 5 & 22 & 3 & 38 \\
\hline \multicolumn{8}{|l|}{ Sphaeromatidae } \\
\hline U. Sphaeromatid & & & 3 & & 6 & 2 & 11 \\
\hline Cymodoce sp. & & & & & & 2 & 2 \\
\hline Cymodoce aculeata grandis & & & & & 1 & & 1 \\
\hline \multicolumn{8}{|l|}{ Eurydicidae } \\
\hline Cirolana sp. & 1 & 3 & 3 & & 13 & 5 & 25 \\
\hline Ourozeuktes sp. & & & & & & 1 & 1 \\
\hline Serolis $\mathrm{sp}$ & & & & & 1 & & 1 \\
\hline U. Amphipod & 3 & 5 & 9 & 7 & 49 & 1 & 74 \\
\hline \multicolumn{8}{|l|}{ Gammaridae } \\
\hline U. Gammarid & & & & & 1 & & 1 \\
\hline \multicolumn{8}{|l|}{ Corophiidae } \\
\hline U. Corophiid & & & & & 1 & & 1 \\
\hline Hyperiidae & & & & & & & \\
\hline U. Hyperiid & & 1 & & & & & 1 \\
\hline
\end{tabular}


Table 5. (Continued)

\begin{tabular}{|c|c|c|c|c|c|c|c|}
\hline \multirow[t]{2}{*}{ Prey item } & \multicolumn{6}{|c|}{ No. of squid containing food items in: } & \multirow[t]{2}{*}{ Total } \\
\hline & Nov. & Dec. & Jan. & Feb. & Mar. & Apr. & \\
\hline \multicolumn{8}{|l|}{ Caridae } \\
\hline Leptochela sydniensis & 7 & 6 & 6 & 8 & 58 & & 95 \\
\hline Brachyuran megalopa larvae & 4 & & & 3 & 1 & & 8 \\
\hline Brachyuran adult & & & 1 & & 23 & 2 & 26 \\
\hline Macropipus corrugatus & & & & & 3 & & 3 \\
\hline \multicolumn{8}{|l|}{ Bodotriidae } \\
\hline U. Bodotriid & & & & & 1 & & 1 \\
\hline Unidentified crustacean & 13 & 22 & 31 & 22 & 96 & 4 & 188 \\
\hline Total No. of squid containing crustaceans & 29 & 44 & 55 & 46 & 278 & 20 & 472 \\
\hline \multicolumn{8}{|l|}{ Miscellaneous } \\
\hline \multicolumn{8}{|l|}{ Gastropoda } \\
\hline Atlantidae sp. & & 22 & & & & & 22 \\
\hline \multicolumn{8}{|l|}{ Insecta } \\
\hline \multicolumn{8}{|l|}{ Orthoptera } \\
\hline U. Cricket & & & & 3 & & & 3 \\
\hline Diptera & & & & & & & \\
\hline U. Psychodid & 1 & & & & & & 1 \\
\hline Not identified & 14 & 12 & 24 & 34 & 13 & 8 & 105 \\
\hline Total No. of squid containing miscellaneous food items & 1 & 34 & 24 & 37 & 13 & 8 & 117 \\
\hline Total No. of feeding squid & 73 & 85 & 111 & 178 & 383 & 82 & 912 \\
\hline Total No. of non-feeding squid & 23 & 57 & 74 & 86 & 108 & 17 & 365 \\
\hline Total No. of squid sampled each month & 96 & 142 & 185 & 264 & 491 & 99 & 1277 \\
\hline
\end{tabular}

which they were found. (Cephalopod prey other than $N$. gouldi have been excluded.) Extrapolating from the regression of Fig. 7 , the mantle lengths of the prey may be estimated as less than $50 \%$ of the mantle length of the squid that ate them.

\section{Measures of Fullness}

As already mentioned, the percentage ratio of gut weight to body weight (\%GW/BW) was taken as the standard measure of gut fullness. When the gut was empty, this was about $3 \%$ of body weight but decreased slightly as the body weight increased (Fig. 10). Correlations were determined between this measure and the fullness indices alone or in combination. The best agreement of the indices was between $\% \mathrm{GW} / \mathrm{BW}$ and the caecum plus stomach $(\mathrm{C}+\mathrm{S})$ index $(r=+0.518, P<0.001)$.

The food was not weighed separately from the gut, but its weight can be inferred for each individual by subtracting from the total gut weight the estimated weight of the empty gut inferred from Fig. 10. These weights, expressed for each animal as a percentage of its body weight, are shown in Table 6 and range from -3 to 24\%. (The small negative values arise because of the variation in empty gut weights as indicated by the spread of points in Fig. 10.) Table 6 also shows the agreement between the $\mathrm{C}+\mathrm{S}$ index and this percentage ratio of estimated weight of gut contents to body weight, e.g. there were three individuals with a $\mathrm{C}+\mathrm{S}$ index of 6 whose gut contents were estimated as $10 \%$ of their body weight. There is considerable scatter in the data but the mean value for maximum fullness $(C+S$ $=8$ ) agrees well with the statement of Wallace et al. (1980) that the average meal of another ommastrephid squid, Illex illecebrosus, in their experimental study constituted $4.5 \%$ of the body weight; and Mercer and Paulmier's (1974) maximum of $13 \cdot 8 \%$ of the body weight also agrees with our data if the single extreme value of $24 \%$ in Table 6 is excluded. Okutani 
(1962) gave a maximum of $8 \cdot 27 \%$ of body weight for the Japanese common squid. (This species was referred to as Ommastrephes sloani pacificus but is now generally called Todarodes pacificus.)

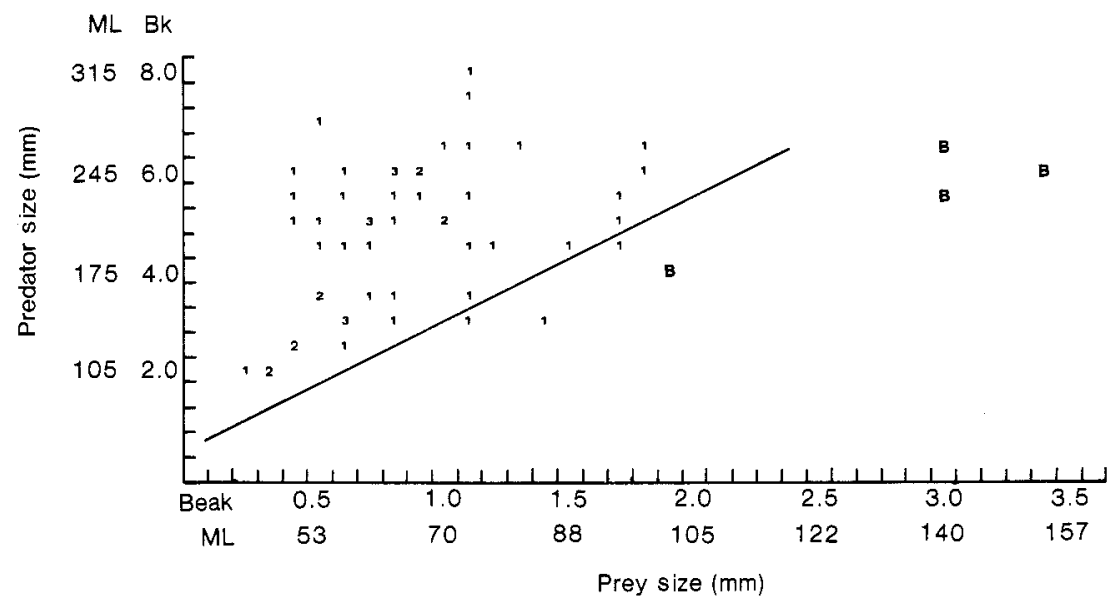

Fig. 9. Distribution of $N$. gouldi beaks found in the stomachs of $N$. gouldi, showing the relative sizes of prey and predator. Numbers within figure are number of examples with this size of prey and predator. $B$, beak was broken. Beaks other than probable $N$. gould $i$ excluded. Mantle length of prey inferred by extrapolation from Fig. 7. Line drawn shows when mantle length of predator is twice mantle length of prey.

Although the mean percentage food weight shows a good agreement with the fullness index, the standard deviations were large, showing that predicting the one from a single reading of the other cannot be done accurately. The reason for this was that there was considerable variation in the weight of the gut itself without food (Fig. 10), ranging from 1 to $11 \%$ of the body weight (mean $3 \cdot 3$, coefficient of variation $36 \%$ ). Because of this uncertainty, we have reported both the $\mathrm{C}+\mathrm{S}$ fullness index and the $\% \mathrm{GW} / \mathrm{BW}$ in giving our results and not relied on our estimates of the weight of the food.

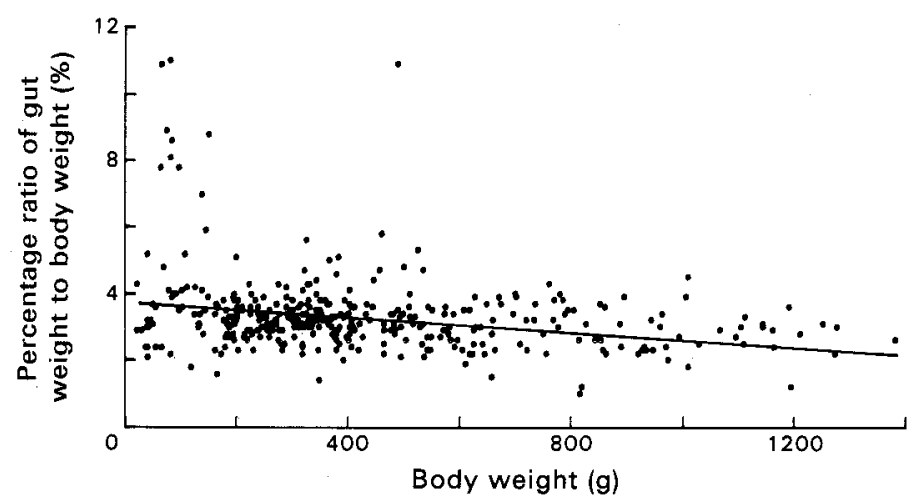

Fig. 10. Relation between percentage ratio of gut weight to body weight when gut is empty and body weight. Regression line is $y=3 \cdot 706-x / 862$.

\section{Diel Changes in Feeding}

Fig. 11 shows that there were changes in the fullness of the squid at different times of day. The different measures of fullness show general agreement, with more food in the animals at night and dawn than at day or dusk. The ratio $\% \mathrm{GW} / \mathrm{BW}$ is least clearcut, probably because of the unexplained variation in the weight of the empty digestive tract. 
The pattern was slightly different in February and March but the differences may represent sampling errors.

Table 6. Relation between fullness index and estimated food in gut

\begin{tabular}{|c|c|c|c|c|c|c|c|c|c|}
\hline \multirow[b]{2}{*}{$\begin{array}{l}\text { Estimated } \\
\text { weight } \\
\text { of gut } \\
\text { contents } \\
\text { (as } \% \text { of } \\
\text { body w1) }\end{array}$} & \multicolumn{9}{|c|}{ No. of animals with fullness index ${ }^{4}$ of: } \\
\hline & 0 & 1 & 2 & 3 & 4 & 5 & 6 & 7 & 8 \\
\hline 24 & & & & & & & & & 1 \\
\hline 14 & & & & & & & & & 1 \\
\hline 13 & & & & & & & & & 1 \\
\hline 12 & & & & & & & & & 1 \\
\hline 11 & & & & & 1 & 1 & 1 & & \\
\hline 10 & & & & & & 2 & 3 & 1 & 1 \\
\hline 9 & & & & & 2 & & 1 & 2 & 1 \\
\hline 8 & 1 & & 1 & & 1 & 1 & 2 & & 3 \\
\hline 7 & 2 & & & & & 1 & 1 & 2 & 7 \\
\hline 6 & 1 & & & & 1 & 2 & 1 & 3 & 5 \\
\hline 5 & 3 & & & & 3 & 1 & 3 & 5 & 6 \\
\hline 4 & 2 & 1 & & 1 & 1 & 3 & 7 & 9 & 10 \\
\hline 3 & 3 & 3 & 4 & 2 & 3 & 6 & 15 & 9 & 15 \\
\hline 2 & 3 & 5 & 2 & 4 & 7 & 11 & 18 & 8 & 10 \\
\hline 1 & 21 & 16 & 9 & 15 & 30 & 43 & 31 & 15 & 7 \\
\hline 0 & 194 & 107 & 53 & 58 & 42 & 39 & 22 & 13 & 3 \\
\hline-1 & 130 & 62 & 38 & 21 & 20 & 16 & 6 & & 1 \\
\hline-2 & 14 & & 4 & 4 & 3 & & & & \\
\hline-3 & 2 & 1 & 1 & & & & & & 1 \\
\hline$n$ & 376 & 195 & 112 & 105 & 114 & 126 & 112 & 67 & 74 \\
\hline Mean & 0.3 & 0.4 & 0.4 & $0 \cdot 5$ & $1 \cdot 3$ & 1.6 & $2 \cdot 7$ & $3 \cdot 2$ & $4 \cdot 9$ \\
\hline s.d. & $1 \cdot 21$ & 0.87 & $1 \cdot 27$ & 0.99 & $2 \cdot 15$ & $2 \cdot 15$ & 2.72 & $2 \cdot 42$ & $3 \cdot 83$ \\
\hline
\end{tabular}

${ }^{A}$ Fullness index of stomach and caecum combined.
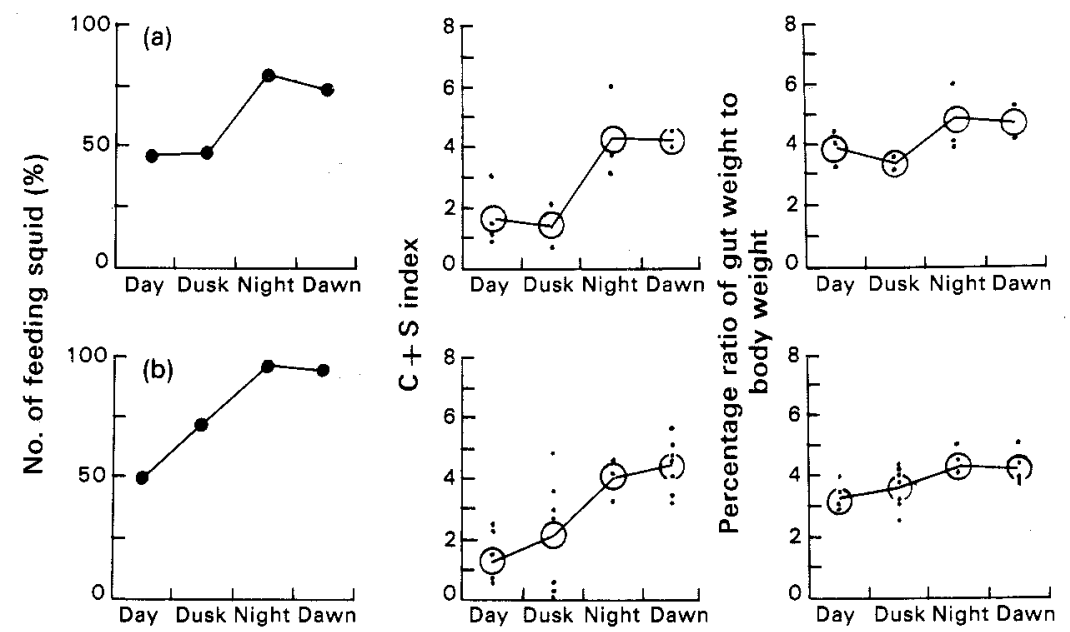

Fig. 11. Three measures of fullness at different times of day in February $(a)$ and March (b) 1980 . - Values for individual samples. O Mean values.

In March only, the catch rate for the machines was recorded. As Fig. 12 shows, there was a marked increase in the average catch rate per machine around sunset with a sharp 
drop in catch rate around dawn. The catch rate was highest during the night and lowest during the day. The changes in catch rate over $24 \mathrm{~h}$ were very similar to the changes in the three measures of feeding (Fig. 11).

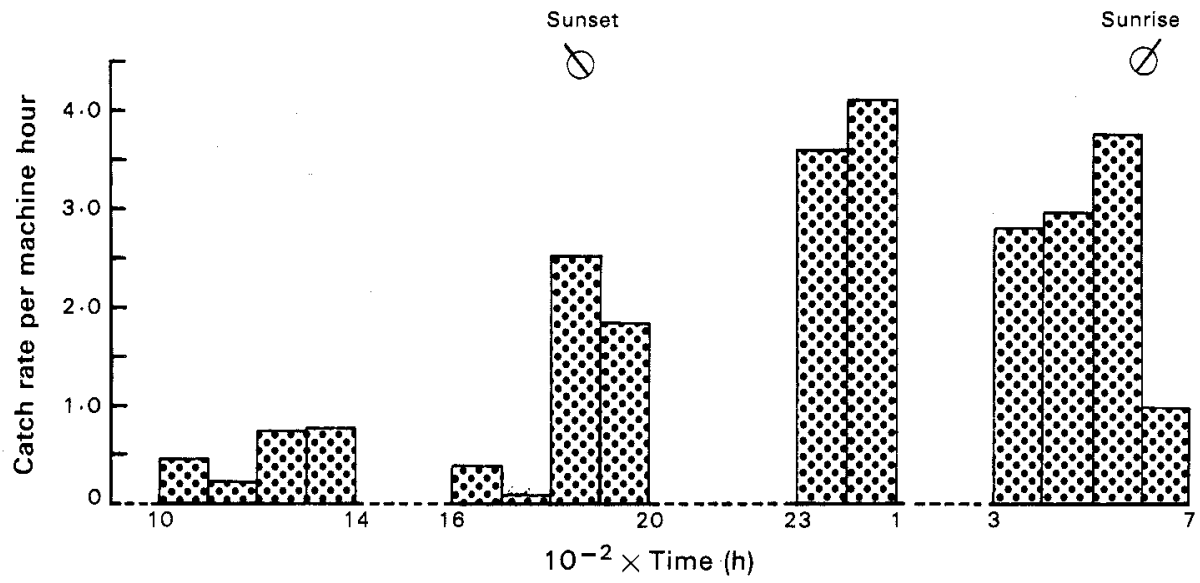

Fig. 12. Average catch per machine hour in March 1980. Times of sunrise and sunset are shown.
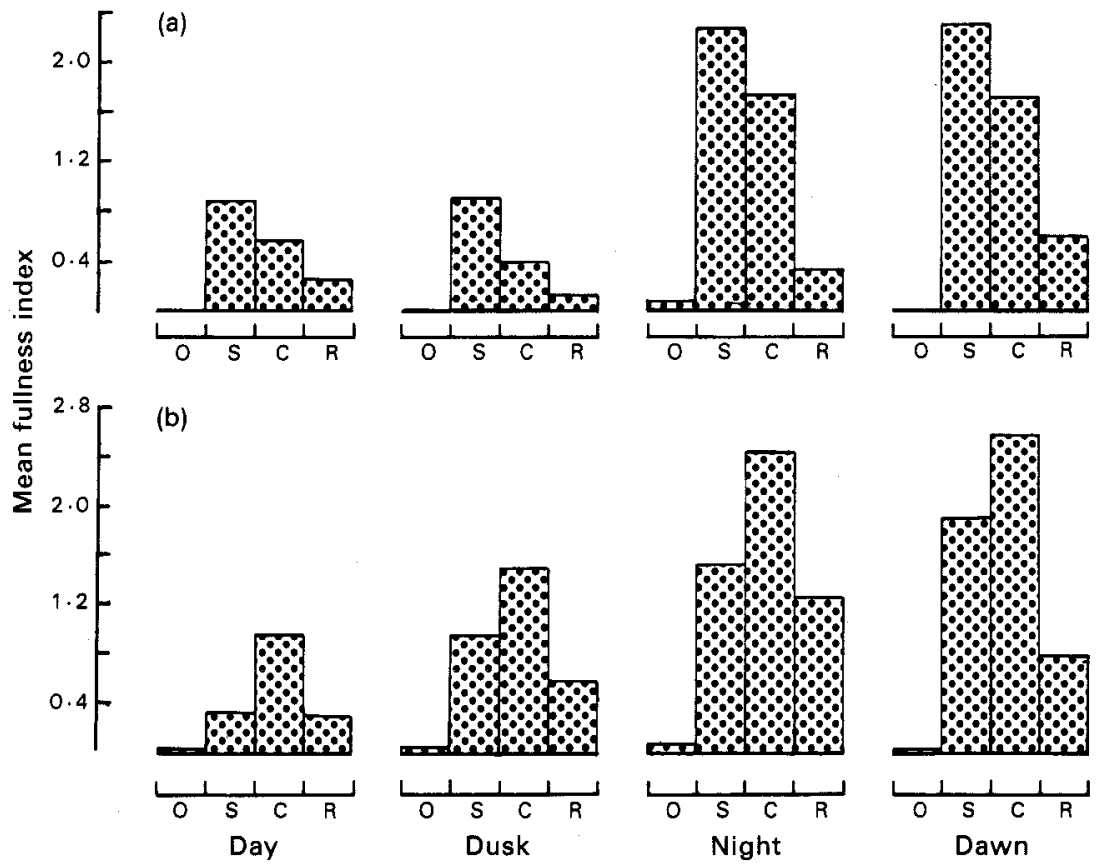

Fig. 13. Mean fullness index over $24 \mathrm{~h}$ for each part of gut during February $(a)$ and March (b) 1980. $O$, oesophagus; $S$, stomach; $C$, caecum; $R$, rectum.

The mean fullness index for each part of the digestive tract was determined separately for day, dusk, night and dawn (Fig. 13). The maximum possible score for the oesophagus and rectum indices was 2 each, and for the stomach and caecum 4 each. The low values 
for the oesophagus at all times presumably indicate that the food passes very quickly into the stomach. For both months, the mean fullness index of all other parts was lowest during the day and dusk periods with an increase at night and dawn. There was no apparent lag

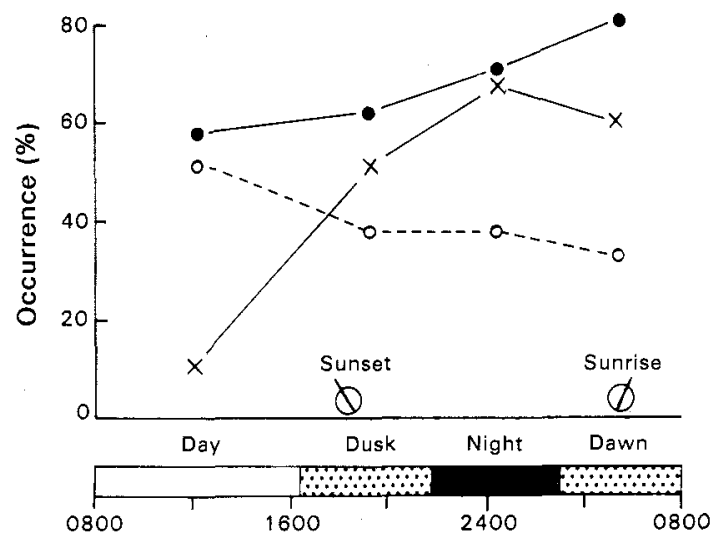

Fig. 14. Percentage of feeding squid in which particular types of food item ( fish; $x$ crustacean; $O$ cephalopod) occurred at different times of day in February and March 1980. Approximate times of sunrise and sunset are indicated.

in the filling of the rectum. The mean values for each part shift by similar amounts as the time of day changes. Presumably the food moves through the gut with little delay in reaching the stomach, caecum and rectum.

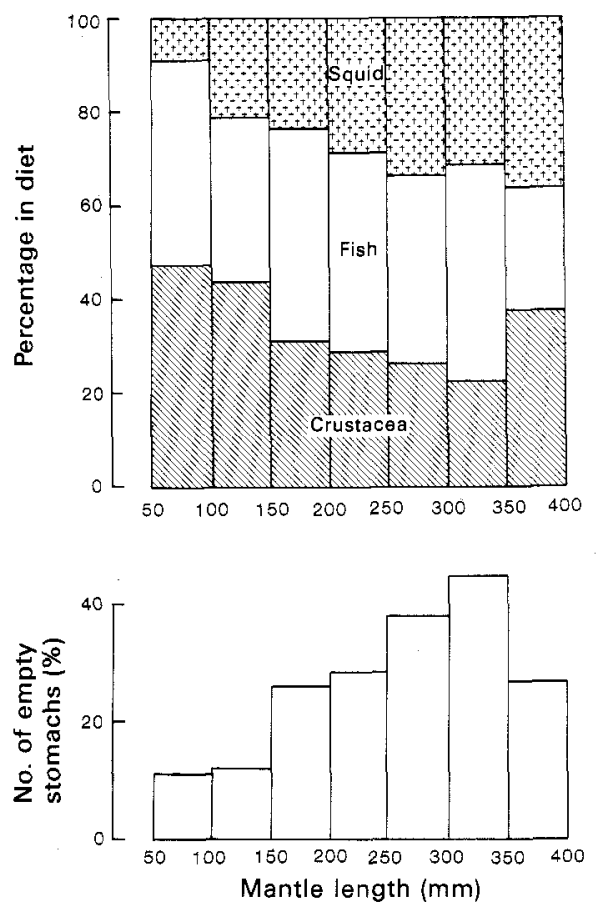

Fig. 15. Changes in diet composition and incidence of empty squid stomachs as a function of mantle length.

The percentage occurrence of the three major food categories among the feeding squid was found to be affected by the time of day (Fig. 14). As can be seen, crustaceans and perhaps fish were more common in the food at night than in the day, and cephalopods were more common by day than at night. 


\section{Sex Differences in Feeding}

To see if there were sex differences in the pattern of feeding, the number of animals with the gut empty was determined for each sex. Of the 678 males $25 \cdot 5 \%$ were empty and $28.7 \%$ of the 599 females had no food, but this difference was not significant $\left(\chi^{2}=\right.$ $1 \cdot 49, P>0 \cdot 05)$. Nor were there differences in the type of food of the two sexes after allowing for body size (see below).
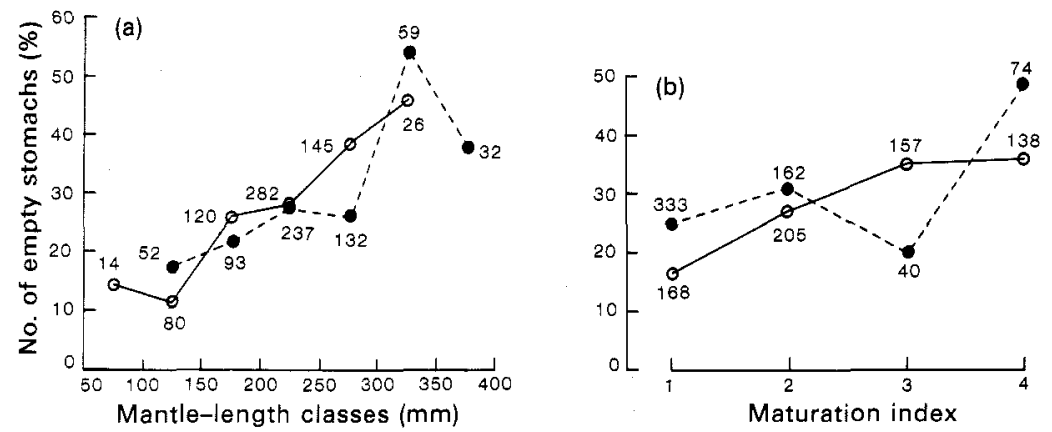

Fig. 16. Changes in incidence of empty squid stomachs, with mantle length $(a)$ and maturation index $(b)$ for males $(O)$ and females $(\bullet)$. Numbers associated with each point represent the number of squid on which each percentage was based.

\section{Body Size, Maturation and Food}

There was a significant increase in the number of animals with the gut empty as body size increased for both males (trend* $\chi^{2}=21 \cdot 83, P<0 \cdot 01$ ) and females (trend $\chi^{2}=11 \cdot 80$, $P<0.01$ ) (Figs 15 and $16 a$ ).

Table 7. Correlations and partial correlations between maturation, mantle length and having no food in the gut $n=1277$

\begin{tabular}{lcc}
\hline \multicolumn{1}{c}{ Correlation } & $r$ & $P^{\mathrm{A}}$ \\
\hline Normal & & \\
$\quad$ Maturation $\times$ mantle length & 0.701 & $<0.01$ \\
$\quad$ Maturation $\times$ no food in gut & 0.142 & $<0.01$ \\
$\quad$ Mantle length $\times$ no food in gut & 0.162 & $<0.01$ \\
& & \\
Partial & 0.694 & $<0.01$ \\
$\quad$ Maturation $\times$ mantle length) $\times$ no food in gut & 0.040 & $>0.05$ \\
(Maturation $\times$ no food in gut $) \times$ mantle length & 0.088 & $<0.01$ \\
\hline (Mantle length $\times$ no food in gut) $\times$ maturation & & \\
\hline
\end{tabular}

${ }^{A}$ For $n=1277, r($ critical $5 \%)=0.046, r($ critical $1 \%)=0.072$.

Fig. $16 b$ shows an apparent trend for an increase in the number of empty squid as the maturation index increased from 1 to 4 . This applied to both males (trend $\chi^{2}=17 \cdot 60$, $P<0.01$ ) and females (trend $\chi^{2}=11.71, P<0.01$ ). However, because size and maturation are correlated it is necessary to examine whether both contribute significantly to the effect

* Maxwell (1961) described a method of analysing contingency tables, which partitions the overall $\chi^{2}$ for homogeneity into a part due to a systematic trend $(\mathrm{d} . \mathrm{f} .=1)$ and the remaining heterogeneity. In the case just mentioned for the male:

$\begin{array}{lccc}\text { Source of variation } & \text { d.f. } & \chi^{2} & \text { Probability level } \\ \text { Due to linear trend } & 1 & 21.83 & P<0.01 \\ \text { Departure from trend } & 4 & 2 \cdot 23 & P>0.05 \\ \text { Overall } & 5 & 24.06 & P<0.01\end{array}$


on feeding. Table 7 gives the correlation and partial correlation coefficients between the three variables. It shows that the partial correlation between size and maturation was almost the same as that for the normal correlation; there was still a significant negative partial correlation between size and feeding. But when the effect of size was excluded, the significant effect disappeared for maturation and feeding; in other words, the apparent correlation between maturation and feeding (Fig. $16 b$ ) was most probably due to the effect of the correlation between size and feeding.

Not only does body size affect the likelihood of squid containing food, but it also affects the type of food (Fig. 15). There was a significant decrease in the number of animals containing crustaceans as the size increased (trend $\chi^{2}=27 \cdot 69, P<0 \cdot 01$ ). There was also an increase, more marked in the lower size classes, in the occurrence of cephalopods as the size increased (trend $\chi^{2}=4.53,0.05>P>0.01$ ). There was no significant trend for fish (trend $\chi^{2}=0.03, P>0.05$ ). Thus, whereas fish were equally common for all sizes, small squid took more crustaceans and large ones were more likely to eat other cephalopods.

\section{Discussion}

Statistically significant differences were found in the food collected from $N$. gouldi in different months (Fig. 8). But before concluding that these represent seasonal changes, we should remember that the samples were collected in different areas in Bass Strait (Fig. 1). In January, February and March, the samples were taken from much the same areas yet differences in the frequencies of the three main food types were still apparent. This is also true when correction is made for the size distributions of the samples taken in the three months and the preference of different-sized squids for different kinds of food (Fig. 15). We may conclude that even in the same part of Bass Strait, the diet of $N$. gouldi changed during the early part of 1980 , no doubt reflecting in part the availability of different foods. The occurrence of heteropods, which were only recorded in December, illustrates the opportunism of $N$. gouldi. The sampling area was different from other months (Fig. 1), and of the 15 samples collected over 9 days, 7 had squid that had eaten heteropods, each of these samples containing several such individuals. Area differences in diet have been reported for Todarodes pacificus (Okiyama 1965) and for Illex illecebrosus (Mercer and Paulmier 1974; Amaratunga et al. 1979).

Other ommastrephids seem to feed on a wide range of organisms (Okutani 1962; Okiyama 1965; Amaratunga et al. 1979; Amaratunga 1980). Nototodarus sloani from New Zealand is reported to take crustaceans (euphausids, amphipods and crab zoea), fish (myctophids and saury) and squid (Saito et al. 1974). N. gouldi appears similarly catholic in diet. The fish that occurred most commonly in the diet in Bass Strait were two abundant species, Sardinops pilchardus and Leionura atun. According to Winstanley (1979) summarizing earlier work, the pilchard, Sardinops pilchardus, occurs in Bass Strait in spring, summer and autumn at least, perhaps all the year round, but in Victorian waters spawning and shoaling at the surface are restricted to shallow, inshore waters. The barracouta, Leionura atun, usually inhabits the middle layer of water (Blackburn and Gartner 1954) but both large and small specimens were observed feeding at night in the surface waters illuminated by the fishing lights. March was the month when the barracouta was identified most commonly in the squids' diet. Over the period November to March, Grant et al. (1978) reported that the species grows from about 40 to $170 \mathrm{~mm}$, well within the size accessible to $N$. gouldi. Not only are barracouta sometimes the prey of squid, they may also be their predators. Large specimens were observed chasing squid in surface waters at night.

Leptochela sydniensis and Cirolana sp. were the two crustaceans most commonly identified in the diet of $N$. gouldi. They and most of the other crustaceans identified are semibenthic, only leaving the safety of the bottom benthos to move into the water at night 
(G. Poore, personal communication). Some were caught on the surface with a dip net. In agreement with this diel pattern, the frequency of occurrence of crustaceans in the diet of the squid increased from about $10 \%$ in the day to over $50 \%$ at night (Fig. 14).

$N$. gouldi also preyed on its own species, and less often on other cephalopods. Several authors have suggested that the extent of apparent 'cannibalism' in Illex illecebrosus may be exaggerated in samples collected by trawling since 'captured squid attack anything with which they come in contact' (Amaratunga et al. 1979; Ennis and Collins 1979). It seemed possible that the same might apply to $N$. gould $i$ caught by jigging because the excited squid lying in the collecting trays and bins may survive up to $30 \mathrm{~min}$. However, though they sometimes attacked each other they were not seen to ingest anything. This was confirmed by the experiment on the samples collected in February and March, which were removed and frozen directly they were caught. The percentage frequencies of squid in the diet of those animals that contained food were 11.8 and 4.7 for February and March, respectively, a similar range to other months when this precaution was not taken $(19 \cdot 2$, November; $3 \cdot 5$, December; $11 \cdot 7$, January; $6 \cdot 1$, April). We may conclude that cannibalism after capture is unimportant for $N$. gouldi captured by jig.

On the basis of seasonal trends in the frequency of empty stomachs, and the proportion of squid in the diet of Illex illecebrosus, Ennis and Collins (1979) suggested that cannibalism is encouraged by a shortage of alternative food. In experimental studies in the laboratory, O'Dor et al. (1980) mention that cannibalism was observed but only when food had not been provided for several days. Amaratunga (1980) suggests that, besides availability, the 'conversion efficiency' may make cephalopods a more favoured food than fish. Our data on $N$. gouldi do not offer any support for the idea that squid are favoured because food is short. When we compared for each sample collected the proportion of squid recorded with empty stomachs (fullness index $=0$ ) with the proportion of those that had some food that contained squid, the correlation was non-significant $(r=0 \cdot 190, n=82)$.

There are no descriptions of the way $N$. gouldi attacks prey but it probably bites up most items into small pieces, ingesting only certain parts, as described for other species (Bidder 1950; Squires 1966; O'Dor et al. 1980; Boletzky 1983). Once the prey is in the stomach and partly digested, it is thus virtually impossible to estimate how many individual items of a given species were involved in the meal. Since time was not available in this study to sort the contents of the digestive tracts and measure the volume (or weights) of different types of food, we relied on the frequency-of-occurrence method to compare the relative importance of different food types in the diet. Most other workers on the diet of squid have done the same.

An important limitation of this method is that no allowance is made for the fact that identifiable traces of some prey (e.g. fish otoliths, squid beaks) may remain longer in the digestive tract than others. Fortunately, in our study, only a few such hard, indigestible parts were found in any single animal, suggesting that any hard parts that remain after one meal are passed out with the undigested remains of the next.

Of the squid examined, $11.5 \%$ had food that could not be identified even to the categories fish, cephalopod or crustacean. If the relative frequency of the different categories was the same in this unidentified material as in the identified material, then the information available would provide a correct picture for the frequency of the different categories. But even if all the unidentifiable food happened to be of one type-an even more unlikely assumption-say fish, then the percentage of fish in the diet would only increase by approximately 10 . Thus, the existence of unidentified prey probably does not greatly distort the overall picture.

Using the frequency-of-occurrence method and combining all the data, the relative amounts of the food categories fish, crustacean and cephalopod were in the ratio 55:52:39, respectively, (Table 4) or, in percentage terms, 37:35:26 of the diet taken as $100 \%$. However, it was noted that cephalopods and fish when present comprised a greater volume of material than crustaceans when present, so that their contribution to the diet in terms of biomass 
must certainly put fish considerably in the lead. Whether cephalopods or crustaceans are of next importance cannot yet be decided. For Todarodes pacificus, Okutani (1962) reports values that correspond to a percentage of fish:crustaceans:cephalopods in the diet of $76: 13: 11$ when estimated by frequency, but in terms of biomass the ratio is 86:9:5.

In any case, such 'average' values can be misleading because of the month-to-month changes in diet, and the differences for squid of different sizes. As mentioned, squid were more common in the diet of larger animals and crustaceans were more common in the diet of smaller ones; fish were represented about equally at all sizes sampled (Fig. 15). A similar bias favouring crustaceans in the diet of smaller squid and/or favouring squid in the diet of larger animals has been reported for a number of other species (Squires 1957; Fields 1965; Hamabe and Shimizu 1966; Tung 1976; Amaratunga et al. 1979; Ennis and Collins 1979; Amaratunga 1980; Boletzky 1983).

The preponderance of crustaceans in the diet of smaller squid can easily be understood because the average size of these prey is likely to be smaller than the alternatives (squid and fish), and smaller predators will generally take smaller prey. For larger animals, it will generally be more cost-effective to attack larger prey (Schoener 1971). It is less obvious why larger squid should increase the proportion of squid to fish in their diet.

For any particular type of prey, size relative to that of the predator is certainly important. O'Dor et al. (1980) describe experiments with the fish Clupea harengus L. as prey of Illex illecebrosus, showing that fish were captured up to a length roughly equal to the mantle length of the squid. Reviewing a range of experiments with cuttlefish, Boletzky (1983) says that 'as a general rule the total length of a fish or prawn should not be much greater than the total length of the cuttlefish; the carapace width of a crab should correspond to not more than one half of the dorsal mantle length ... There is no definite lower size limit for prey.'. For the squid Sepioteuthis sepioidea, LaRoe (1971) found that 'each of the foods found was only suitable for a definite size range. The squid would not attack prey that were too large or too small.'. The relation between the size of predator and prey could be demonstrated very clearly in the present study because the beak size of the squid prey was measured as well as that of the predator. Fig. 9 shows no evidence for a lower limit of prey size taken, but there is clearly an upper limit, the mantle length of the prey seldom exceeding half that of the predator. It is probably no accident that in the few cases where the beak size indicated relatively larger prey, the beaks were mostly broken ( $B$, Fig. 9), implying a more elaborate handling process than for the smaller ones.

From the way they approach and attack prey, cuttlefish and probably squid appear to use vision when feeding (Messenger 1968, 1977; Bradbury and Aldrich 1969; Hurley 1976; Boletzky, personal communication). It is, therefore, perhaps surprising that several species appear to feed mainly at night, as attested by the nocturnal squid jigging industry. Our data for $N$. gouldi indicate abrupt changes in catchability at sunrise and sunset (Fig. 12) and information on the amount of food in the gut confirms the same general pattern (Fig. 11). (We may discount the measure \%GW/BW, the unreliability of which has been already discussed.) The amount of food in the gut clearly increases at dusk or later, remaining high till dawn. Although the digestion time of $N$. gouldi is not known, the passage of the food from the stomach to the rectum is rapid (Fig. 13), and by the sampling period in the daytime the amount of food in the digestive tract had substantially decreased. Boucher-Rodoni (1975) found for Illex illecebrosus that at temperatures of $8-13^{\circ} \mathrm{C}$ about three-quarters of a meal was digested within $6 \mathrm{~h}$.

As regards other squid, the peak feeding time for Symplectoteuthis oualaniensis (Lesson) is early night with a minimum stomach volume before dawn (Tung 1976). For Todarodes pacificus, Okiyama (1965) correlated the increased number of feeding to non-feeding animals with sunset and the arrival of the deep scattering layer at the surface waters. A different pattern was reported by Amaratunga et al. (1979) for Illex illecebrosus where the percentage of squid with something in the stomach was greatest during daylight hours and 
peaked a few hours before sunset. It may be noted that in that study, Illex illecebrosus were sampled by trawling rather than by jigging.

Okiyama's finding draws attention to the likelihood that the vertical migration of cephalopods may well be related to feeding. Reviewing the evidence at the time, Roper and Young (1975) concluded that ommastrephids showed a variety of vertical migration patterns, some species showing substantial movements, others only slight ones (see also Clarke and Lu 1975; Lu and Clarke 1975). Nototodarus hawaiensis (Berry) is a species that spends much time close to the bottom but approaches the surface nightly through much of the year. According to the fishing master of the Hoya Maru, echo-sounder traces indicated that $N$. gouldi do the same. Bass Strait is shallow, less than $100 \mathrm{~m}$ over much of its area, and the squid remain close to the bottom (and therefore further from the jigs) by day and move up at night. As already mentioned, a number of crustaceans in the diet are mostly benthic and are thought to move into the water column at night. It is just at this time that the frequency of crustaceans in the food increases (Fig. 14). The lights used by the fishing boats when jigging probably distort the distribution of the squid to some extent though it is difficult to assess the importance of this factor. The lights probably attract animals from a wide area and possibly draw them closer to the surface. At night, some $N$. gouldi come right to the surface in the illuminated water. D.O.S. observed animals chasing and sometimes catching fish there. Ogura (1983) also reports that Todarodes pacificus are attracted to a hooked squid and two or three may follow one up to the surface. But most animals probably remain well below the surface, even at night. Maeda and Aso (1974) reported the catch rate of $T$. pacificus at night for the different jigs in the series from the deepest to those closest to the surface. From the non-linear relation between catch rate and depth, it would appear that the number of catchable squid increased with depth at least down to $20 \mathrm{~m}$.

In certain cephalopods, animals approaching spawning reduce their feeding activity or stop completely [e.g. Octopus vulgaris Lamarck (O'Dor and Wells 1978; Wodinsky 1978) and Loligo opalescens Berry (Fields 1965)]. In ommastrephids, the situation seems less clear as spawning is much less well known. O'Dor et al. (1980) found that in the laboratory, females of Illex illecebrosus ceased to feed as their ovaries developed, and at the same time the digestive system appeared to become greatly reduced. Nothing was said of the males. Furthermore, starvation induced experimentally in females of this species is reported to promote the growth of gonads and nidamental glands (Rowe and Mangold 1975). As maturity is associated with size, one might therefore expect that field data would indicate that large animals were more likely to contain less food. Squires (1957) found some relation between size and the percentage of animals empty but it was not consistent, whereas Amaratunga et al. (1979) found the reverse trend, though only weakly, with larger animals more often one-half full of food than smaller ones. In $N$. gouldi, we found there was a tendency for more mature squid of both sexes to be empty more often than immature animals, with no significant difference between the sexes (Fig. 16). But, as discussed earlier, this appears to be associated more closely with size rather than their maturation, though the two are closely associated (Table 7).

Two suggestions may be proposed for why larger animals should more often be empty. Since size is linked with maturation, it may be that in a semelparous species, as most cephalopods are thought to be, all resources are increasingly directed, as spawning approaches, into reproduction rather than into obtaining food. This is presumably the explanation in Octopus vulgaris in which the gonads may physically constrict the filling of the stomach as they enlarge (O'Dor and Wells 1978). But the experiments of Rowe and Mangold (1975) indicate that it is unlikely that this is a purely passive process. Alternatively, it may reflect larger size and the decreasing metabolic costs this entails (Schmidt-Nielsen 1975). Comparing squid towards either end of the range represented in Fig. 15, a large animal of $350 \mathrm{~mm}$ ML weighs about 46 times as much as a small one of $100 \mathrm{~mm}$ ML. Corresponding to this size difference, the metabolic rate per gram of body weight of the 
larger animal would be only about $38 \%$ that of the smaller (assuming the value of 0.75 for the slope relating log of metabolic rate to log of weight; Schmidt-Nielsen 1975). If the meal sizes of squid are proportional to their weights, this implies, other things being equal, that the larger squid need to feed, on average, only $38 \%$ as often as the smaller ones. It is not known how the digestion time for larger squid compares with that for smaller ones (Boucher-Rodoni 1975) but a change of the magnitude indicated in Fig. 15 from 10\% of the time empty to $40 \%$ would seem possible.

A discrepancy exists between the data presented here for the allometric relation between mantle length and weight and that found by Harrison (1983) and Smith (1983) for the same species. Harrison and Smith both found that the exponent of the relation, $k$, was larger for the males than for the females, and Smith showed that the difference was highly significant: Harrison-o $3 \cdot 1658$, \& $3 \cdot 1073$; Smith $-\$ 3 \cdot 2128$, \& $2 \cdot 869$. In our study, based on fewer animals, there were small differences in monthly samples, only once marginally significant, with the exponent sometimes larger for the female, sometimes for the male. Overall, there was no significant difference between the sexes (* $3.099, \& 3.079)$. Without adequate statistical examination, it seems premature to infer that there are or are not population differences in the weight-mantle-length relation, such as Lange and Johnson (1981) report in other species.

Little conclusive evidence was provided in the study about the timing of spawning in Bass Strait in 1979-1980. Over the whole sampling period from November to April, those females with a mantle length above $300 \mathrm{~mm}$ maintained a uniformly high maturation index (Table 3), the greatest percentage of females with large nidamental glands occurring in December and January. As already mentioned, it was during December that large, mature females were most frequently collected. January was the month when the larger females (and males) faded out of the samples (Fig. 5), as if dying after spawning or moving elsewhere to spawn. Possibly, therefore, December-January was the peak spawning period in the year but spawning may well have extended over several months.

In March, but at no other time between November and April, a new cohort of young squid with a mantle length under $120 \mathrm{~mm}$ appeared in the samples (Fig. 5). We do not know when they would have been spawned, but S. Boletzky (personal communication) has estimated that it would probably take at least 3 or 4 months from spawning until $N$. gouldi are large enough to be caught by jigging.

On the basis of the time that new cohorts appear in the fishery, Harrison (1983) has reported that the timing of spawning differs slightly in different parts of Bass Strait and neighbouring Tasmanian waters and that in some years it appeared to be more concentrated than others; he also failed to find any clearly defined spawning period in 1979-1980. However, the spawning grounds have not yet been located and early larval stages are hardly known.

\section{Acknowledgments}

Dr C. C. Lu, National Museum, Victoria, provided the expertise on cephalopods at all stages in this study and jointly supervized the Honours thesis on which it is based. Drs M. Gomon and G. Poore, also of the National Museum, provided indispensable assistance in the identification of other taxa (fishes and Crustacea, respectively). We appreciate the hospitality and help of Mr S. Machida and the crew of the JAMARC research vessel Hoyo Maru 67 and the services of Mr J. Thompson, Victorian Institute of Marine Sciences, in organizing a berth on board for D.O.S. Dr P. E. Roberts, Marine Science Laboratories, Queenscliff, kindly provided unpublished data on the distribution and abundance of arrow squid and major predators in Victorian coastal waters. Several other members of staff of the Fisheries and Wildlife Division of the Ministry for Conservation, Victoria provided material and advice, for which we are grateful. Drs Lu and Ian Bayly also offered valuable suggestions in the preparation of this manuscript. The photographs were made with the help of Ron Waters and the figures were mostly prepared by Mark Hindell. 


\section{References}

Allan, J. K. (1945). Planktonic cephalopod larvae from the eastern Australian coast. Rec. Aust. Mus. 6, 317-50.

Amaratunga, T. (1980). Preliminary estimates of predation by the short-finned squid (Illex illecebrosus) on the Scotian Shelf. Northwest Atl. Fish. Org., SCR Doc. 80/11/31, Serial No. 63.

Amaratunga, T., and Durward R. D. (1979). Standardization of data collection for the short-finned squid, Illex illecebrosus. Int. Comm. Northwest Atl. Fish. Sel. Pap. 5, 37-41.

Amaratunga, T., Neilson, J. D., Gillis, D. J., and Valdron, D. G. (1979). Food and feeding of the short-finned squid, Illex illecebrosus on the Scotian Shelf in 1978. Int. Comm. Northwest Atl. Fish. Res. Doc. 79/11/11. Serial No. 5335.

Anon. (1978). Report of feasibility study on squid jigging fisheries in the south western Pacific Ocean, 1977. JAMARC Rep. No. 18.

Anon. (1980). Report of the feasibility study 1978 on squid jigging fisheries in the south western Pacific Ocean. JAMARC Rep. No. 19.

Arnold, G. D. (1979). Squid. A review of their biology and fisheries. Minist. Agric. Fish. Food, Direct. Fish Res., Lowestoft, Lab. Leafl. No. 48.

Bidder, A. M. (1950). The digestive mechanism of the European squids, Loligo vulgaris, L. forbesii, Alloteuthis media and A. subulata. Q.J. Micros. Sci. 91, 1-43.

Blackburn, M., and Gartner, P. E. (1954). Populations of barracouta Thyrsites atun (Euphrasen) in Australian waters. Aust. J. Mar. Freshw. Res. 5, 41-68.

Boletzky, S. (1983). Diets for cephalopods. Mem. Nat. Mus. Vic. 44. (In press.)

Boucher-Rodoni, R. (1975). Vitesse de digestion chez les cephalopodes Eledone cirrosa (Lamarck) et Illex illecebrosus (Le Sueur). Cah. Biol. Mar. 16, 159-75.

Bradbury, H. E., and Aldrich, F. A. (1969). Observation of feeding of the squid Illex illecebrosus (LeSueur, 1821) in captivity. Can. J. Zool. 47, 913-15.

Clarke, M. R. (1962). The identification of cephalopod 'beaks' and the relationship between beak size and total body weight. Bull. Br. Mus. Nat. Hist. 8, 419-80.

Clarke, M. R. (1977). Beaks, nets and numbers. Symp. Zool. Soc. Lond. 38, 89-126.

Clarke, M. R., and Lu, C. C. (1975). Vertical distribution of cephalopods at $18^{\circ} \mathrm{N} 25^{\circ} \mathrm{W}$ in the North Atlantic. J. Mar, Biol. Assoc. 55, 165-82.

Cotton, B. C. (1942). Cephalopods from stomach contents of fish from east and south Australia. Trans. R. Soc. South Aust. 66, 83-4.

Dunning, M. (1983). Ecological studies of ommastrephid squid in Australian waters. Mem. Nat. Mus. Vic. 44. (In press.)

Ennis, G. P., and Collins, P. W. (1979). Food and feeding of the short-finned squid, Illex illecebrosus, during its seasonal occurrence in the Newfoundland area. Int. Comm. Northwest Atl. Fish. Sel. Pap. 5, 25-9.

Fields, W. G. (1965). The structure, development, food relations, reproduction, and life history of the squid Loligo opalescens Berry. Calif. Dep. Fish Game Fish. Bull. No. 131.

Grant, C. J., Cowper, T. R., and Reid, D. D. (1978). Age and growth of snoek, Leionura atun (Euphrasen), in south-eastern Australian waters. Aust. J. Mar. Freshw. Res. 29, 435-44.

Hamabe, M., and Shimizu, T. (1966). Ecological studies on the common squid, Todarodes pacificus Steenstrup, mainly in the southwestern waters of the Japan Sea: Bull. Jpn Sea Reg. Fish. Res. Lab. 16, 13-55.

Harrison, A. J. (1983). Assessment of a squid fishery off Tasmania. Mem. Nat. Mus. Vic. 44. (In press.)

Hurley, A. C. (1976). Feeding behavior, food consumption, growth and respiration of the squid Loligo opalescens raised in the laboratory. U.S. Fish Wildl. Serv. Fish. Bull. 74, 176-82.

Kawakami, T. (1976). The fishery biological study on a squid, Nototodarus sloani sloani (Gray), in New Zealand waters. Bull. Tokai Reg. Fish. Res. Lab. 85, 31-104.

Lange, A. M., and Johnson, K. L. (1981). Dorsal mantle length total weight relationship of squids Loligo pealei and Illex illecebrosus from the Atlantic coast of the United States. NOAA Tech. Rep. NMFS, Spec. Sci. Rep. Fish. Serv. No. 745, pp. 1-17.

LaRoe, E. T. (1971). The culture and maintenance of the loliginid squids Sepioteuthis sepiodea and Doryteuthis plei. Mar. Biol. 9, 9-25.

Lu, C. C., and Clarke, M. R. (1975). Vertical distribution of cephalopods at $40^{\circ} \mathrm{N}, 53^{\circ} \mathrm{N}$ and $60^{\circ} \mathrm{N}$ at $20^{\circ} \mathrm{W}$ in the North Atlantic. J. Mar. Biol. Assoc. 55, 143-63.

Maeda, H., and Aso, K. (1974). The distribution pattern of squids caught by the automatic powered reel. J. Shimonoseki Univ. Fish. 22, 115-45. 
Maxwell, A. E. (1961). 'Analysing Qualitative Data.' (Methuen: London.)

Mercer, M. C. (1973). Sexual maturity and sex ratios of the ommastrephid squid, Illex illecebrosus (LeSueur) at Newfoundland (subarea 3). Int. Comm. Northwest Atl. Fish., Res. Doc. No. 73/79.

Mercer, M. C., and Paulmier, G. (1974). Distribution and biological characteristics of the short-finned squid (Illex illecebrosus) on the continental shelf of subareas 3 and 4 in May-June, 1973. Int. Comm. Northwest Atl. Fish., Res. Doc. No. 74/87.

Messenger, J. B. (1968). The visual attack of the cuttlefish, Sepia officinalis. Anim. Behav. 16, 342-57.

Messenger, J. B. (1977). Prey-capture and learning in the cuttlefish, Sepia. Symp. Zool. Soc. Lond. 38, 347-76.

Nelson, J. B. (1980). 'Seabirds, their Biology and Ecology.' (Hamlyn: London.)

O'Dor, R. K., Durward, R. D., Vessey, E., and Amaratunga, T. (1980). Feeding and growth in captive squid, Illex illecebrosus, and the influence of food availability on growth in the natural population. Int. Comm. Northwest Atl. Fish., Sel. Pap. 6, 15-21.

O'Dor, R. K., and Wells, M. J. (1978). Reproduction versus somatic growth: hormonal control in Octopus vulgaris. J. Exp. Biol. 77, 15-31.

Ogura, M. (1983). Fishing gear and fishing techniques for squid in Japan. Mem. Nat. Mus. Vic. 44. (In press.)

Okiyama, M. (1965). On the feeding habits of the common squid, Todarodes pacificus Steenstrup, in the offshore region of the Japan Sea. Bull. Jpn Sea Reg. Fish. Lab. 14, 31-41.

Okutani, T. (1962). Diet of the common squid, Ommastrephes sloani pacificus landed around Ito Port, Shizuoka Prefecture. Bull. Tokai Reg. Fish. Res. Lab. 32, 41-7.

Roberts, P. E. (1978). New Zealand squid resources. Fish. Res. Div. Occas. Publ. (N.Z.) No. 15, pp. 90-3.

Roper, C. F., and Young, R. E. (1975). Vertical distribution of pelagic cephalopods. Smithson. Contrib. Zool. 209, 1-51.

Rowe, V., and Mangold, $\mathrm{K}$. (1975). The effect of starvation on sexual maturation in Illex illecebrosus (LeSueur) (Cephalopoda:Teuthoidea). J. Exp. Mar. Biol. Ecol. 17, 157-63.

Saito, R., Kawakami, T., Hamabe, M., and Matsushita, Y. (1974). Preliminary note on the ecology of the ommastrephid squid Nototodarus sloani sloani (Gray) in New Zealand waters. Bull. Tokai Reg. Fish. Res. Lab. 79, 35-68.

Schmidt-Nielsen, K. (1975). ‘Animal Physiology: Adaptation and Environment.' (Cambridge University Press: London.)

Schoener, T. W. (1971). The theory of foraging strategies. Ann. Rev. Ecol. Syst. 2, 369-404.

Slack, E. B. (1973). Squid fisheries in Australian and New Zealand waters. World Fish. 22, 42-65.

Smith, H. (1983). Fisheries biology of Nototodarus (sloani) gouldi. Mem. Nat. Mus. Vic. 44. (In press.)

Squires, H. J. (1957). Squid, Illex illecebrosus (LeSueur) in the Newfoundland fishing area. J. Fish. Res. Board Can. 14, 693-728.

Squires, H. J. (1966). Feeding habits of the squid, Illex illecebrosus. Nature (London) 211, 1321.

Tung, I. H. (1976). On the food habit of common squid, Symplectoteuthis oualaniensis (Lesson). Rep. Inst. Fish. Biol., Minist. Econ. Aff, Natl Taiwan Univ. No. 3, pp. 49-66.

Wallace, I. C., O'Dor, R. K., and Amaratunga, T. (1980). Sequential observation on gross digestive processes of Illex illecebrosus. Northwest Atl. Fish. Org., SCR Doc. 80/11/29, Serial No. NO 61.

Warneke, R. (1976). Preliminary report on the distribution and abundance of seals in the Australasian region. FAO Scientific Consultation on Marine Mammals, Bergen, Norway (Aug./Sept. 1976), Working Paper No. ACMRR/MM/SC42.

Windell, J. T. (1971). Food analysis and rate of digestion. In 'Methods for Assessment of Fish Production in Fresh Waters'. (Ed. W. E. Ricker.) IBP Handbook No. 3. pp. 215-26. (Blackwell: Oxford.)

Winstanley, R. H. (1978). Food of the trevalla Hyperoglyphe perosa (Richardson) off south-eastern Australia. N.Z. J. Mar. Freshw. Res. 12, 77-9.

Winstanley, R. H. (1979). Pilchard and anchovy. CSIRO Div, Fish Oceanogr., Fish. Sit. Rep. No. 3.

Wodinsky, J. (1978). Feeding behaviour of broody female Octopus vulgaris. Anim. Behav. 26, 803-13.

Wolfe, D. C. (1973). Tasmanian surveys put to good use. Aust. Fish 32(3), 6-9.

Wormuth, J. H. (1976). The biogeography and numerical taxonomy of the oegopsid squid family Ommastrephidae in the Pacific Ocean. Bull. Scripps Inst. Oceanogr. Univ. Calif. No. 23. 